AL.2. $1996-345$

C. 2

\title{
Guide to the \\ Common Native \\ Trees and Shrubs \\ of Alberta
}
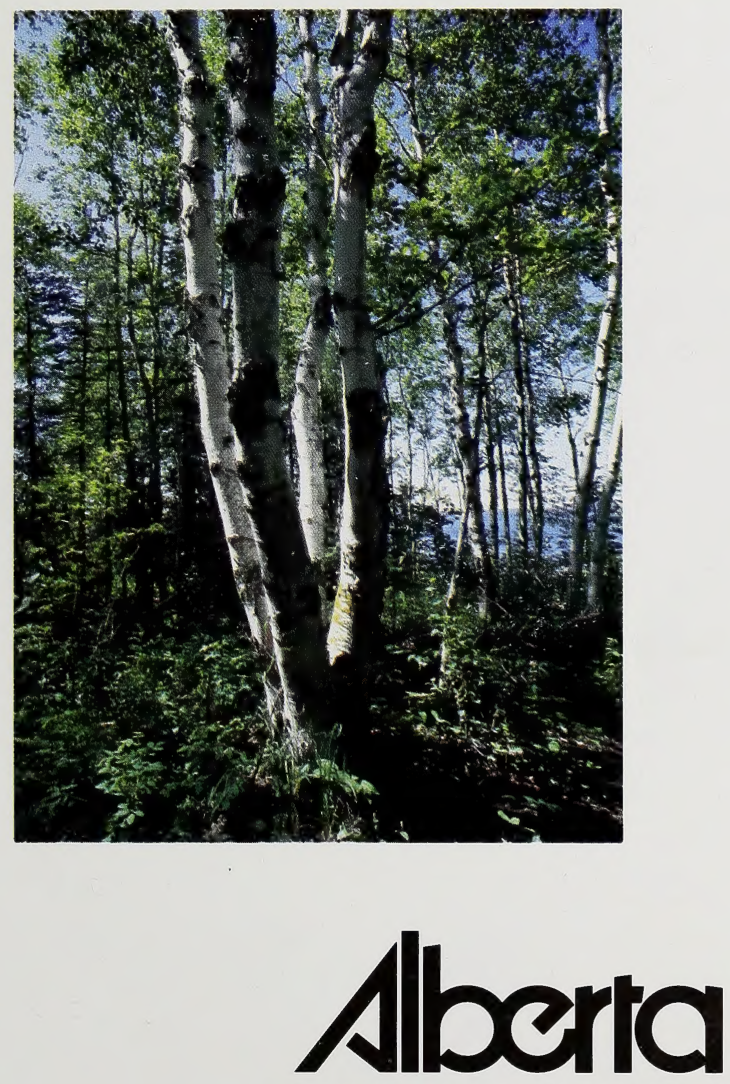

ENVIRONMENTAL PROTECTION 


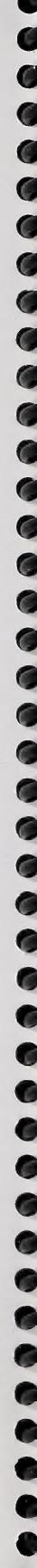




\section{Guide to the Common Native Trees and Shrubs of Alberta}

Wayne Inkpen and Rob Van Eyk

CANADLANA

MAR 281995

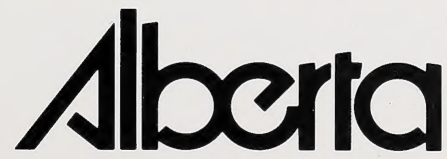

ENVIRONMENTAL PROTECTION Environmental Regulatory Services Pesticide Management Branch 



\section{Table of Contents}

\section{Page}

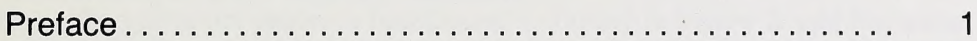

Acknowledgements $\ldots \ldots \ldots \ldots \ldots \ldots \ldots \ldots \ldots \ldots, 1$

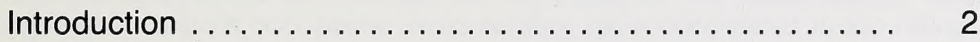

Illustrated Glossary of Terms ................... 4

How To Use Key $\ldots \ldots \ldots \ldots \ldots \ldots \ldots \ldots \ldots \ldots \ldots \ldots$

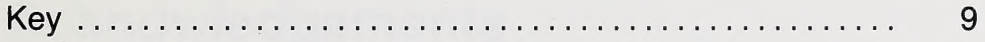

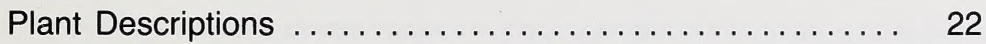

Table — Importance of Shrubs to Wildlife ............ 51

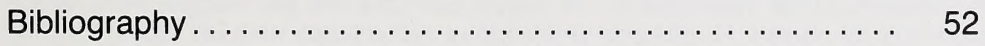

Index of Common and Scientific Names .............. 54 



\section{Preface}

There are several references on plant identification available to Albertans. However, these publications are generally not suited for field use. This guide has been prepared to assist vegetation managers in the identification of the 29 most common woody plants found in Alberta. It is hoped that the knowledge thus gained will assist vegetation management personnel and pesticide applicators to make sound vegetation and management decisions and provide recreationalists with additional enjoyment when they are in Alberta's woodlands.

One does not require a background in forestry or botany to use this guide. A minimal number of technical terms have been used and an illustrated glossary has been included to allay any difficulties the user may have with botanical terms. To aid identification, a written description of each tree and shrub has been included, along with photographs and an illustrated line key based on leaf characteristics. Where applicable, species with similar characteristics have been noted in the narrative descriptions.

Instructions on how to use the illustrated line key are included, along with a table listing the importance of the various shrubs to wildlife, and a selected reference list for those interested in more detailed information.

\section{Acknowledgements}

Among the many people involved in the preparation of this guide, special thanks are due to the following for their noteworthy contributions: Mr. M. Allen for his line key and technical review; Mrs. J. Hrapko and Mr. D. Blackmore for their constructive suggestions, photographs and technical review; Mr. R. Vic and Dr. B. Dancik for their constructive suggestions and technical review; Mr. H. Anderson, Mr. D. Johnson and Mr. D. Pledger for their constructive suggestions and Mrs. H. Inkpen for the charts and illustrations. 


\section{Introduction}

There are 12 major vegetation types in Alberta. Within each of these types one or more of the trees and shrubs listed in this guide can be found.

The narrative descriptions of the woody plants included in this guide follow a systematic order which is in accordance with the classification system used by botanists.

Each description is headed by the tree or shrub's common name and scientific name. The scientific names are in Latin and usually comprise two words. The first word is the generic name and the second word is the species name. The last part of the scientific name usually refers to the individual who named the plant. Scientific names were included because a tree or shrub can have one or more common names. For example, Populus tremuloides Michx. is known as aspen poplar, trembling aspen and white poplar. Because common names can be localized and vary from region to region the scientific name is the only name that precisely identifies a plant.

Following a plant's common and scientific names, a brief description of the plant's shape, size, leaves, flowers, fruit and distribution has been included.

Based on the characteristics of their leaves, the trees in this guide can be split into one of two groups: coniferous trees and deciduous trees. All of the shrubs in this guide are deciduous shrubs. Coniferous trees are commonly referred to as evergreens, softwoods or needle-leafed trees, and with the exception of tamarack, all of the trees in this group retain their leaves for two or more years.

The deciduous trees and shrubs are most often referred to as broadleaf trees or shrubs. Deciduous trees are also known as hardwoods. All of the trees and shrubs that fall into this group drop their leaves in the autumn. 


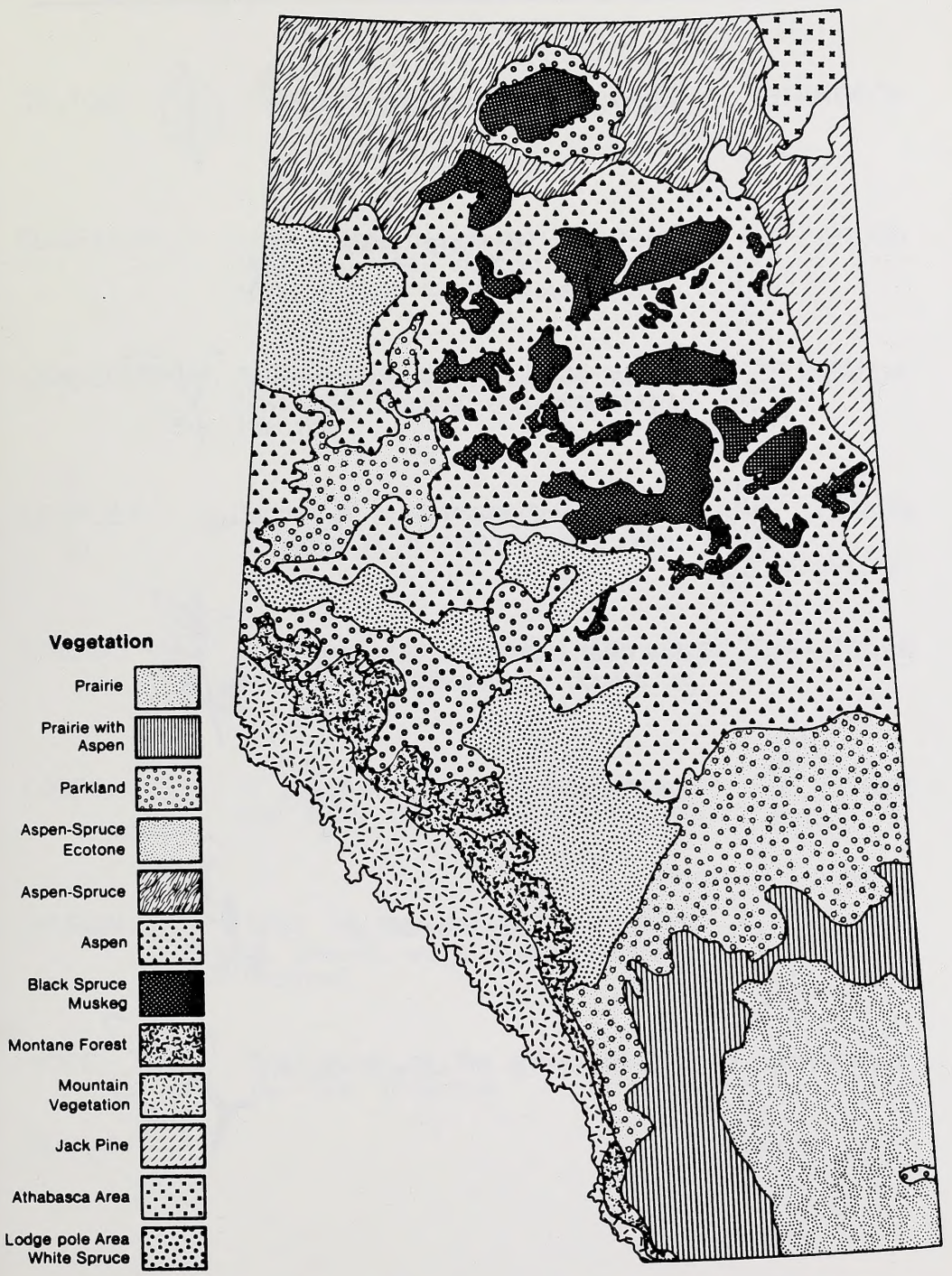

This map has been reproduced from Flora Of Alberta with permission from $\mathrm{Dr}$. John G. Packer. Botany Department, University of Alberta. 
ACUMINATE: Tapering to a long, sharp point.

ACUTE:

Tapering to a sharp point.

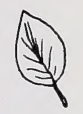

ALTERNATE: Leaves placed singly at different heights along a stem.

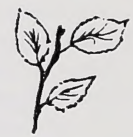

BLADE:

Flat part of the leaf.

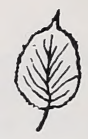

BRACT:

Modified leaf below a flower or branch of flowers.

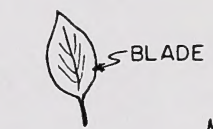

BRISTLY:

Many fine, stiff hairs.

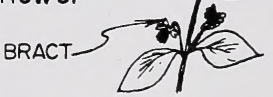

CATKIN:

A flexible, scaly cluster of unisexed flowers.

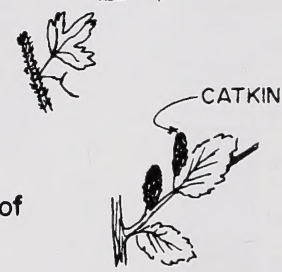

COMPOUND: Leaf made up of several leaflets.

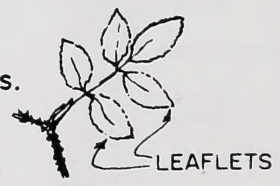




\section{GLOSSARY}

DELTOID: Triangular leoves.

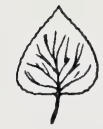

ELLIPTICAL: Leaves that are longer than they are wide, tapering at the tip and base to an acute point.

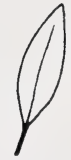

LANCEOLATE: Norrow, long leaves, broad at the base and tapering to a point at the tip.

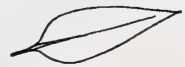

LEAFLET:

Blade of a compound leaf attached to a common leaf stem.

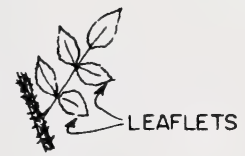

LINEAR:

Long and narrow leaves with parallel margins.

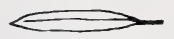

LOBED:

A particular type of leaf in which the blade is prominently indented.

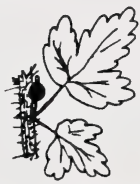

MARGIN:

Edge of the leaf blade, described as smooth, wavy, or serrated (toothed).

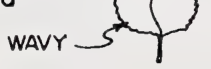

NODE :

The place on the stem where the leaf originates.

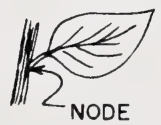




\section{GLOSSARY}

OBLONG:

Leaves that are longer than they are wide, rounded at the base and tip.

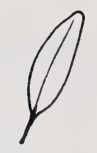

OBOVATE:

Egg shaped leaves, broadest near the tip.

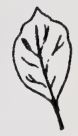

OPPOSITE:

Two leaves originating at the same point on opposite sides along a stem.

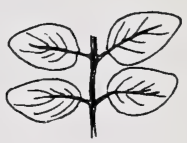

OVAL:

Egg shaped leaves, usually tapered at tip and leaf base.

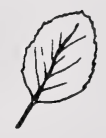

OVATE:

Egg shaped leaves, broadest at the base.

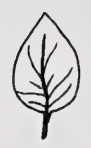

PETIOLE:

Leaf stem; attaches to node and base of leaf.

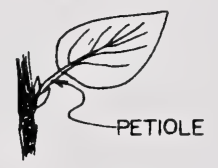

PRICKLY: Sharp, thick spines attached on twigs and stems.

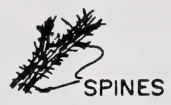

SERRATED: Saw-toothed.

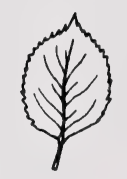




\section{GLOSSARY}

SHEATH:

A clear tubular envelope at the base of a leaf.

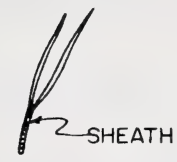

SIMPLE LEAF: Single bladed leaf.

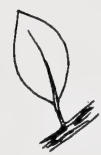

VEIN: Prominent lines on the leaf blade.

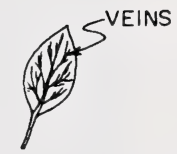

WHORL:

Three or more leaves or leaflets originating from the same node.

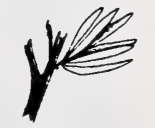




\section{How To Use The Key}

The key is an aid to help you identify the most commonly occurring woody shrubs and young sapling-size trees in Alberta on the basis of summer characteristics. In some cases, other obvious features such as bark colour and texture, are also mentioned.

On the next page is a master key outlining the organization of the main identifying features using a branching network of two contrasting features. The following steps will show you how to get the most use out of the key:

STEP 1: Start at the top of the chart (page 9) at the TYPE OF LEAF, and then work progressively down the page. You should work with at least three leaf samples taken from various parts of the plant.

STEP 2: Since trees and woody shrubs in Alberta have either a BROADLEAF character or a NEEDLE LEAF character, this step organizes all the common plants into two groups.

STEP 3: The illustrations beside each feature will guide you as to the meaning of the features used. If in doubt about a word meaning, see page 4 , the ILLUSTRATED GLOSSARY OF TERMS.

STEP 4: Once you have worked your way through the chart on page 9, you will have noticed a page number beneath the last feature in that particular branch of the key. Go to that page in the text and you should see several possibilities as to the identity of the plant. You will also notice that the stepby-step feature identification which you used in the chart on page 9 is reproduced for that particular branch of the key.

STEP 5: Finally you are left to choose among several possibilities as to the exact name of the plant you are identifying. Read over each description, and determine which one best "fits" the plant you have. 


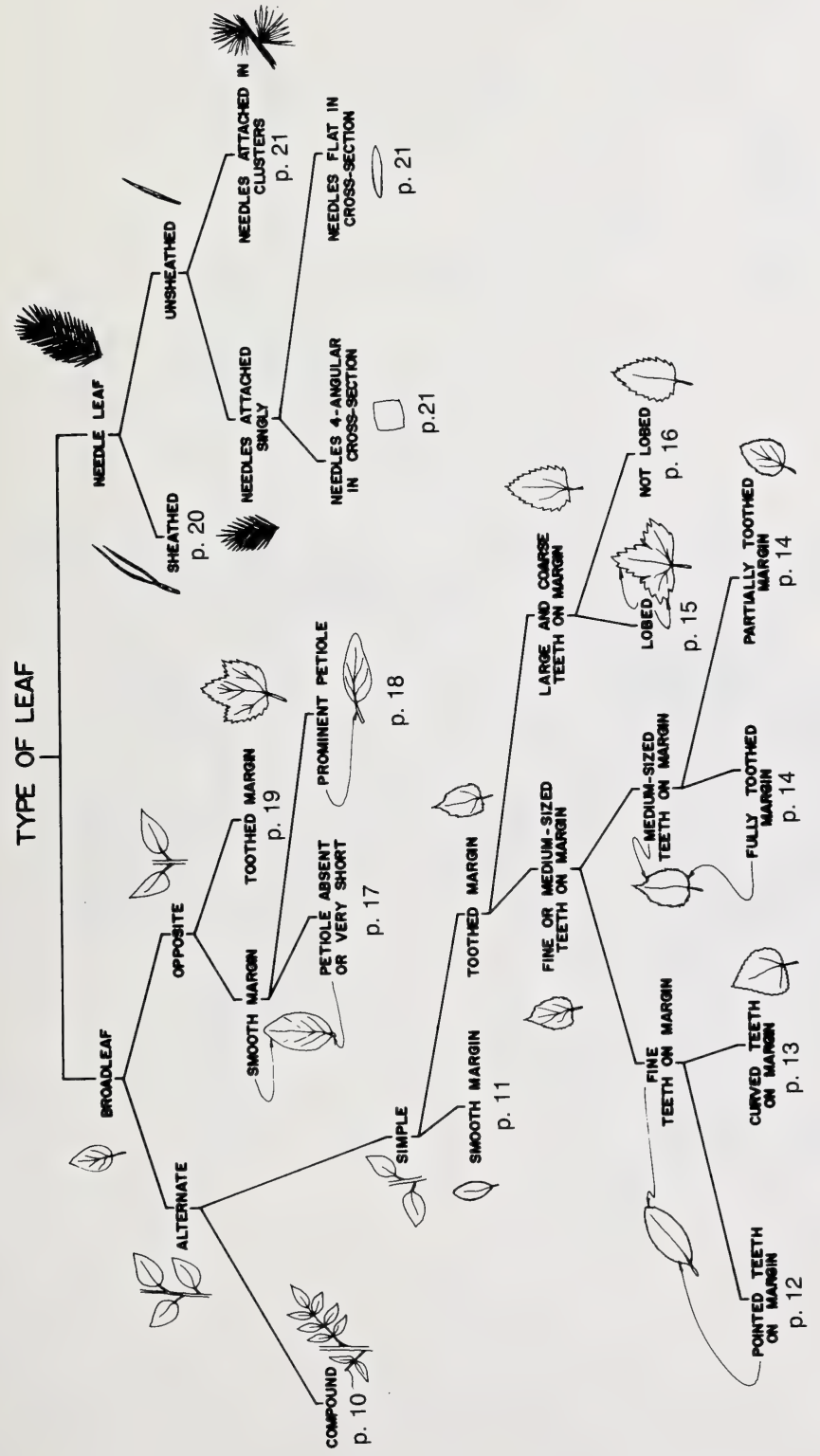



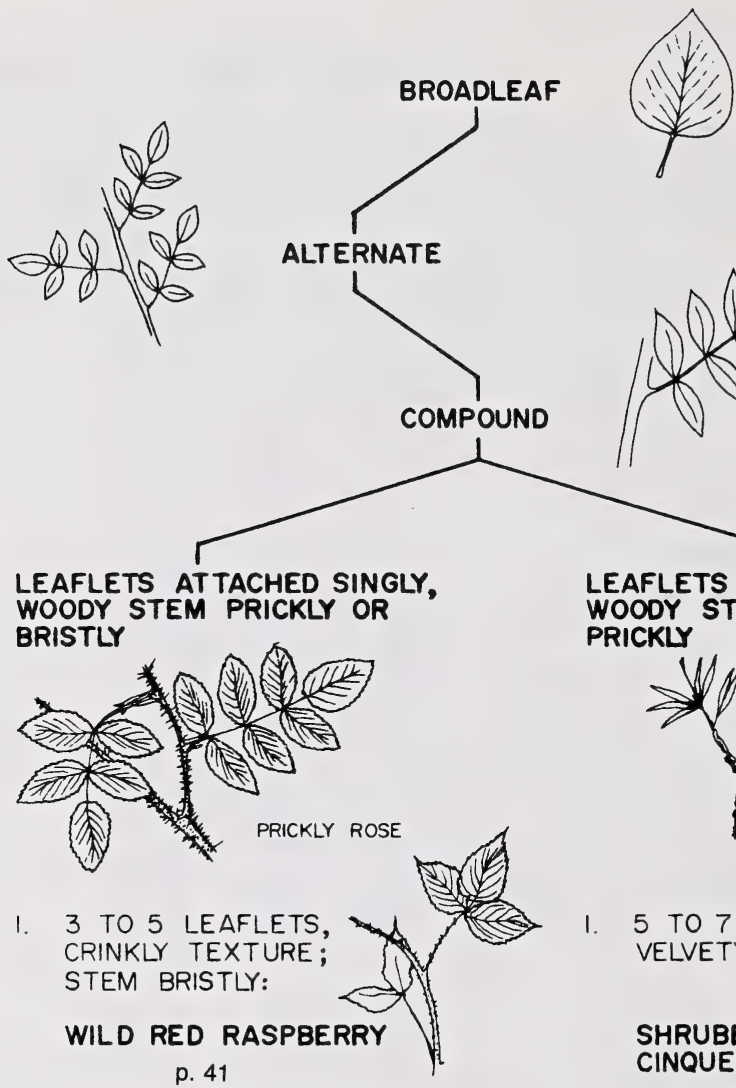

2. 5 TO 7 (USUALLY 7) LEAFLETS,

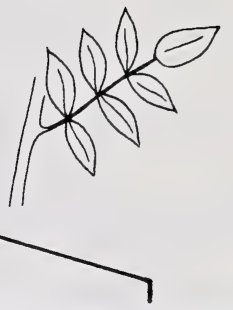

LEAFLETS CLUSTERED, WOODY STEM NOT PRICKLY

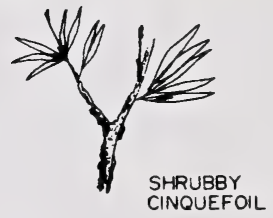

5 TO 7 LEAFLETS, VELVETY TEXTURE:

\section{SHRUBBY}

CINQUEFOIL

p. 37

NO CRINKLY TEXTURE; STEM PRICKLY

PRICKLY ROSE

p. 40 


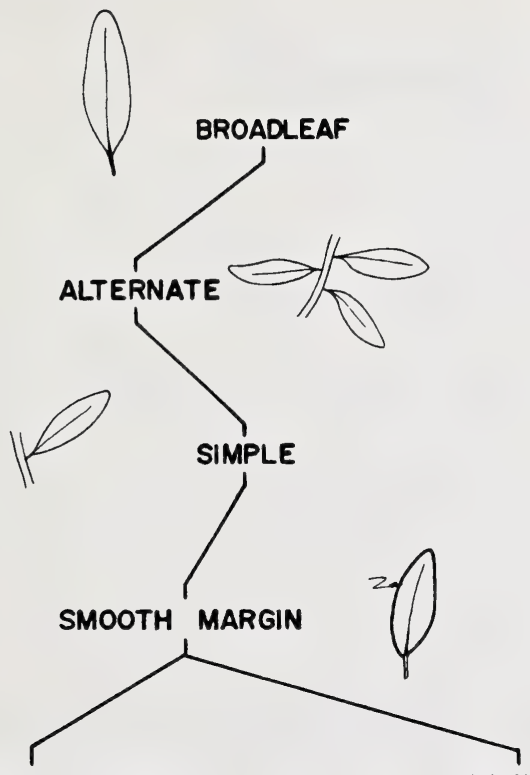

SILVER-GREY SURFACE

LEAF OVATE TO OBLONG, 2 5-8 CM. LONG, BROWNISH SCALES ON UNDERSIDE:

WOLF WILLOW

p. 42

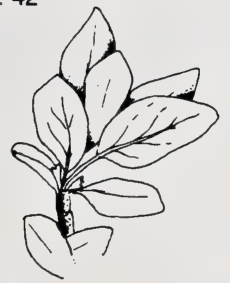

DARK GREEN SURFACE

1. LEAF ELLIPTICAL, I-4 CM. LONG, HAIRY MARGINS, SHORT PETIOLES:

BLUEBERRY

p. 46

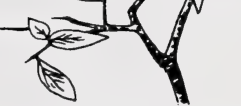

2. LEAF OBLONG TO

ELLIPTICAL, I-5 CM. LONG, RUSTY - WOOLLY UNDERSIDE :

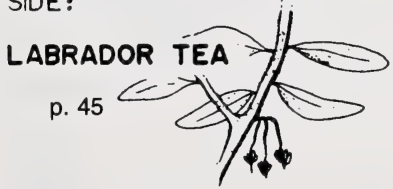




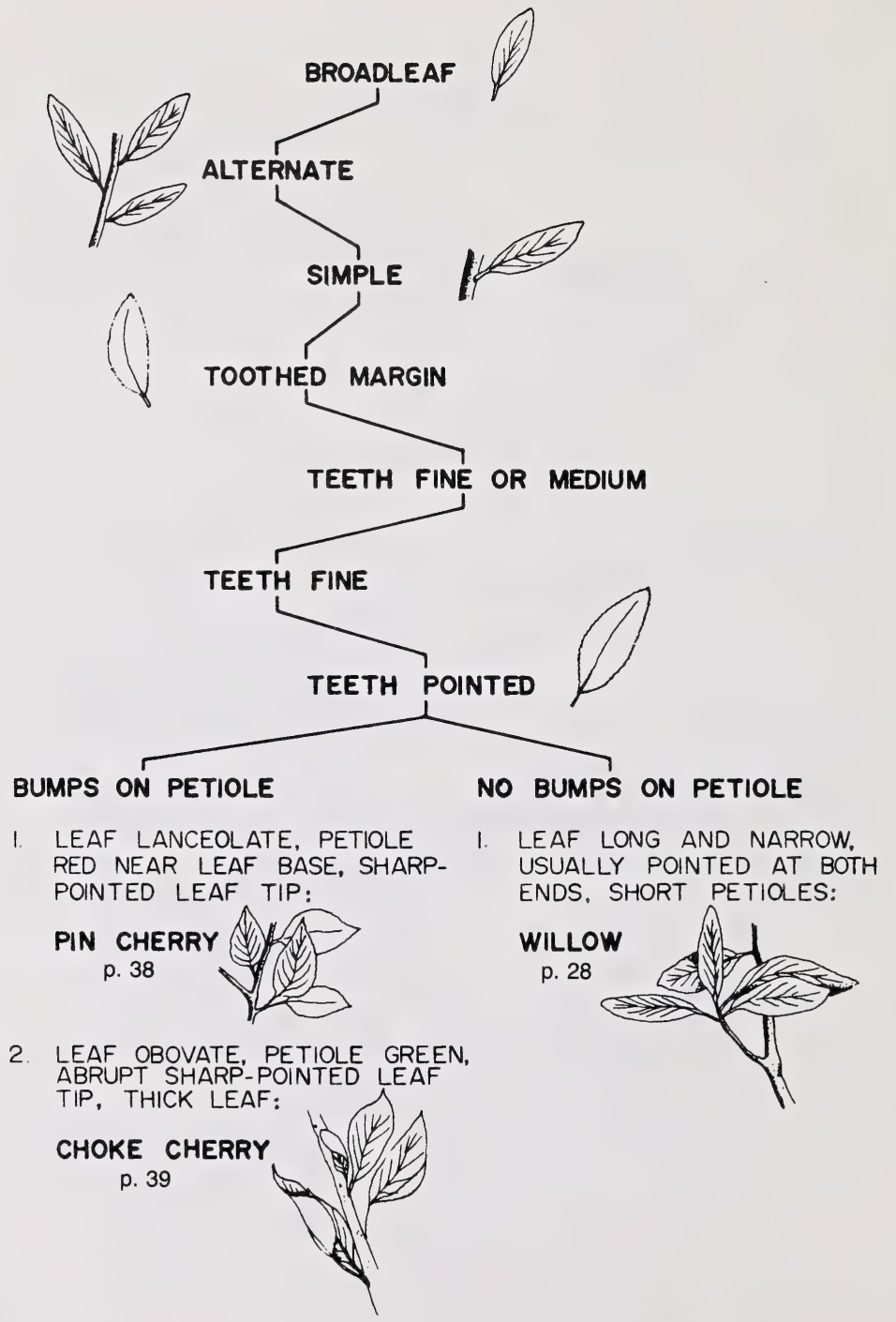




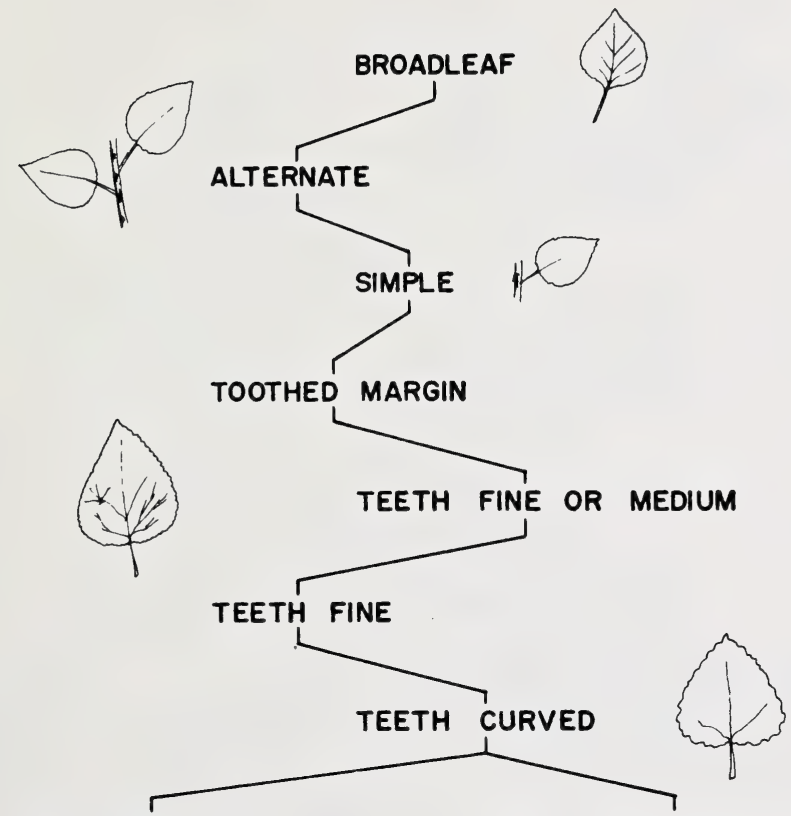

LEAF OVATE TO OVAL

1. SHARP-POINTED TIP, LEAF STEM SLENDER AND FLATTENED:

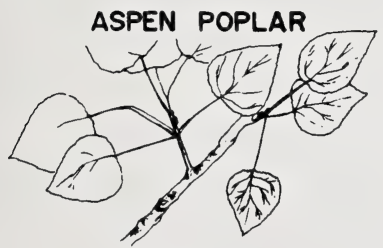

p. 29
LEAF ELLIPTICAL TO OVAL

1. LEAF STEM STOUT AND ROUND, DISTINCT RUSTCOLORED RESIN PATCHES UNDERNEATH:

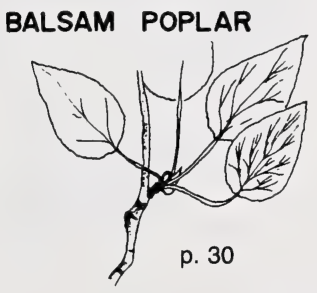




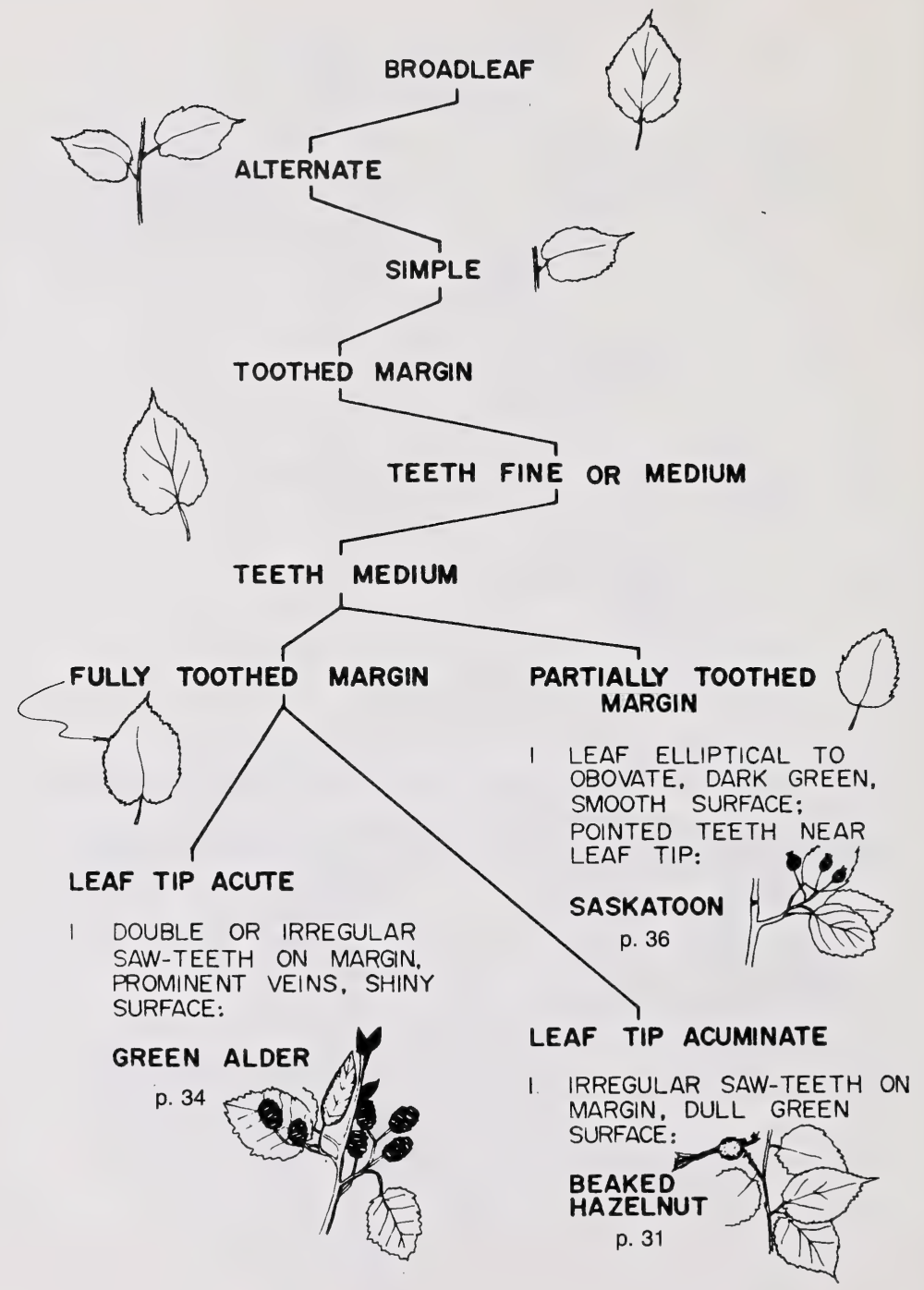




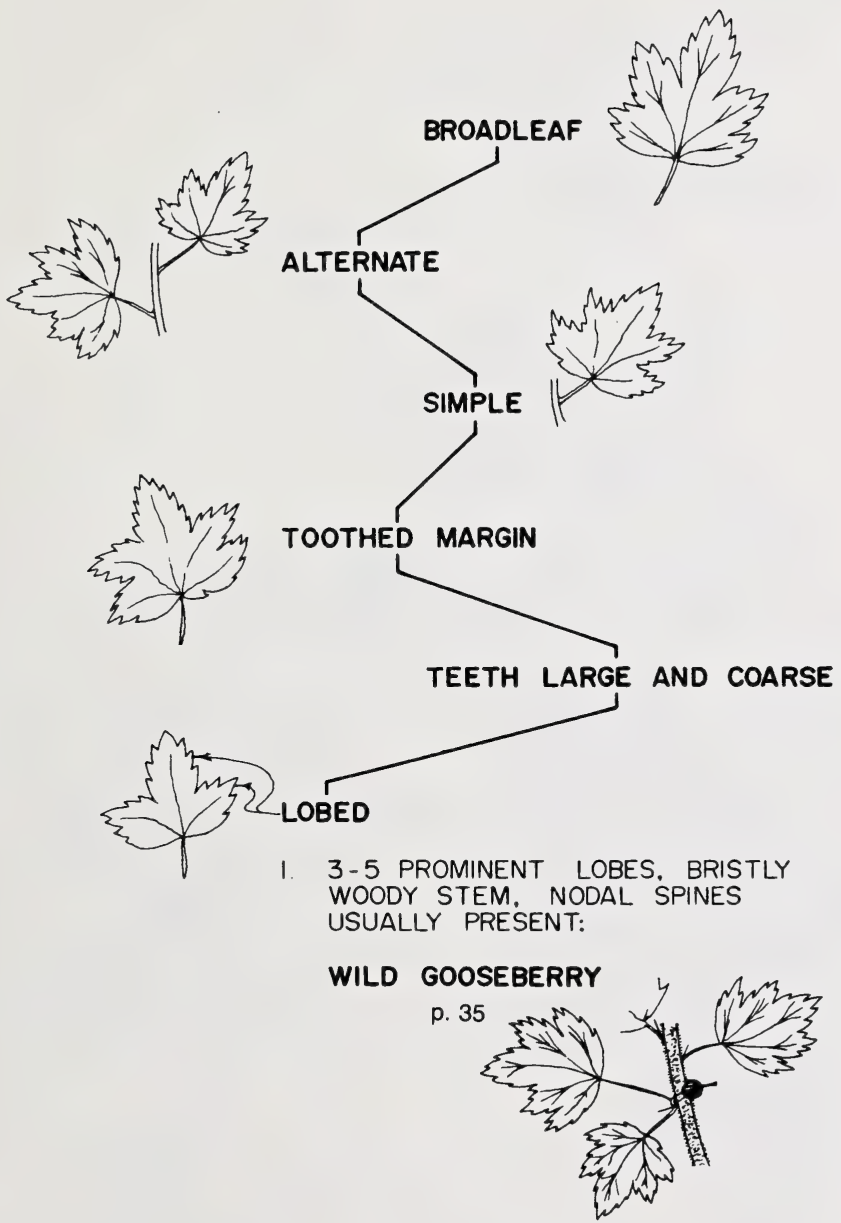


16
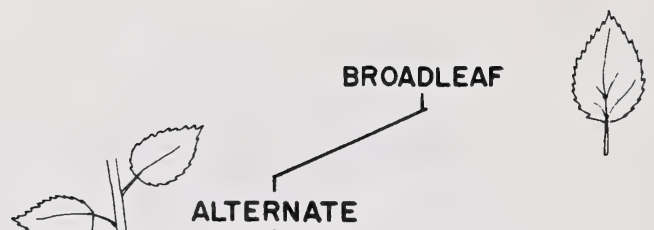

ALTERNATE

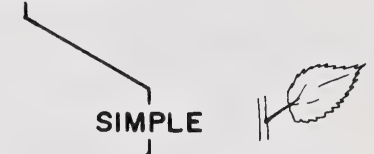

LEAF ROUND TO OBOVATE

I. DULL GREEN, TEXTURED SURFACE; ROUNDED TEETH ON MARGIN, NO TEETH AT BASE; PROMINENT WHITE DOTS (RESIN GLANDS) ON STEMS:

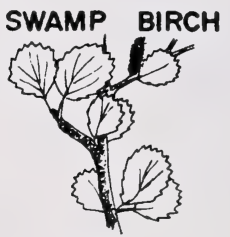

p. 33
LEAF OVATE

I DULL GREEN, TEXTURED SURFACE; SERRATED MARGIN, BASE USUALLY WITHOUT TEETH; SCALY, PURPLE -RED TO WHITE, THIN BARK:

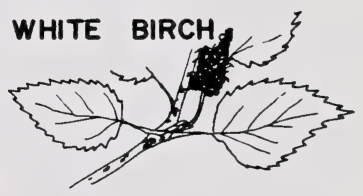

p. 32 


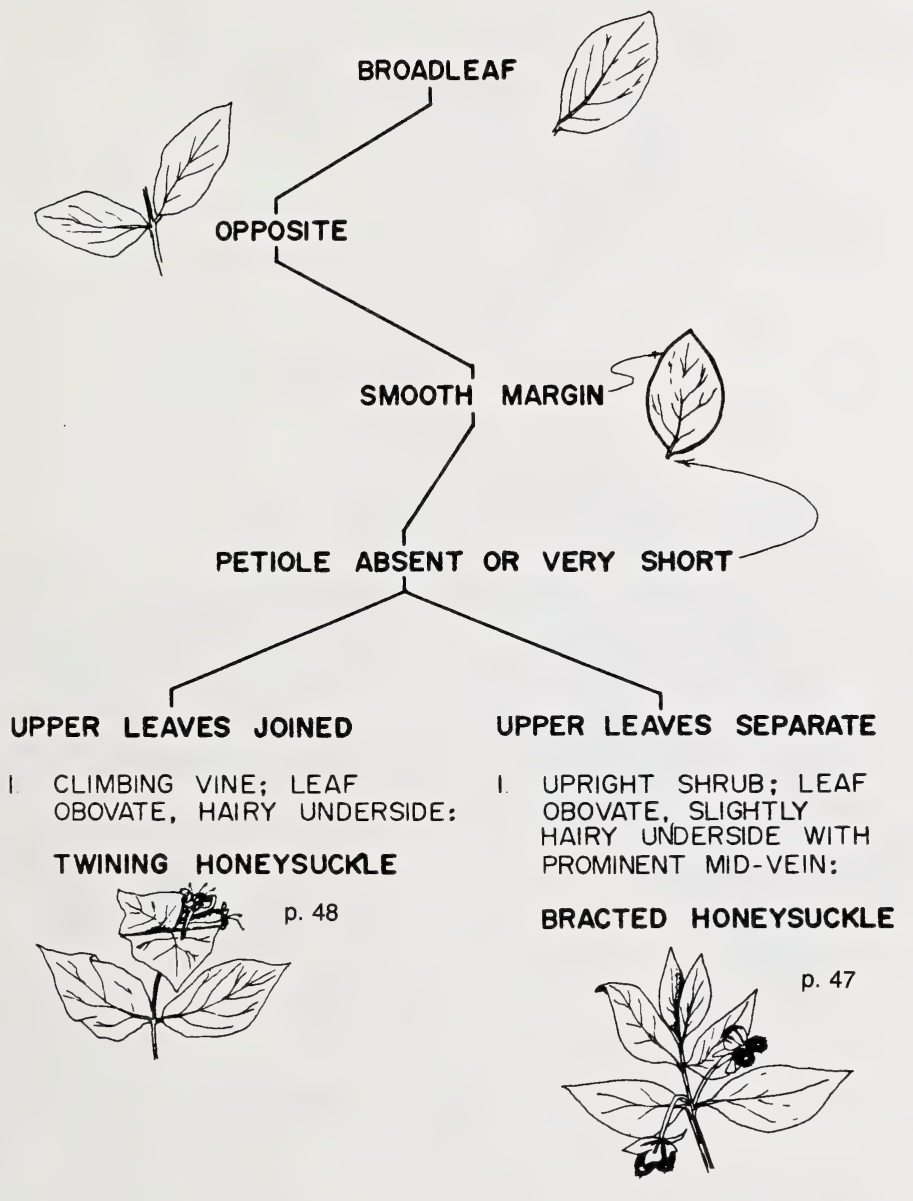




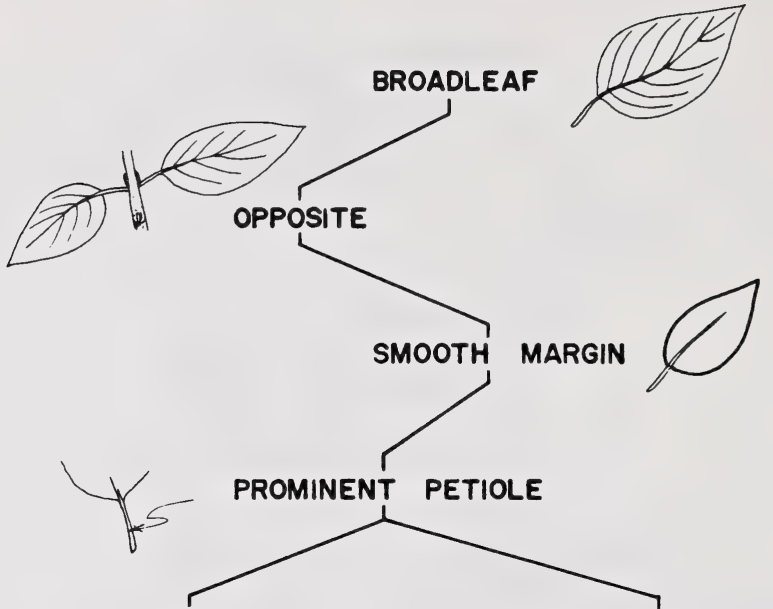

LEAF NARROW. LINEAR

I. LEAF OLIVE COLORED WITH SILVER UNDERSIDE; OCCASIONALLY RUST-BROWN SPOTS ON UNDERSIDE:

CANADIAN BUFFALO-BERRY

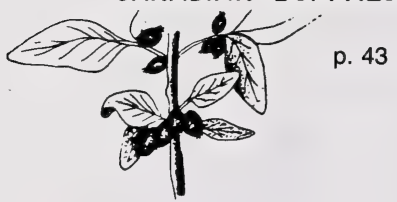

LEAF OVAL TO OVATE

1. LEAF LARGE AND SHARPLY POINTED. PROMINENT ARCHING VEIN CURVING TOWARD TIP: RED-PURPLE STEMS:

RED OSIER DOGWOOD

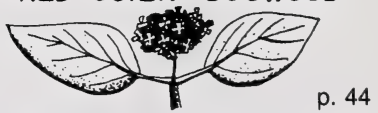

2. LEAF SMALL, THICK AND LEATHERY: HAIRY UNDERSIDE:

BUCKBRUSH

p. 49 


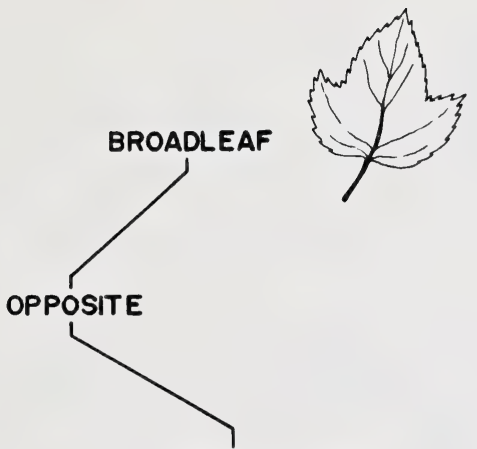

TOOTHED MARGIN

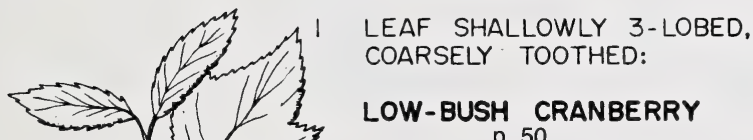

p. 50 


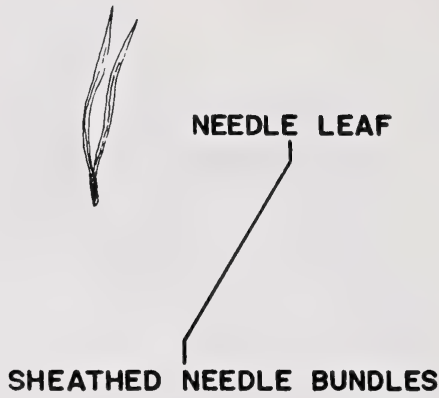

1. BUNDLES OF 2 NEEDLES, STRAIGHT TO SLIGHTLY TWISTED:

JACK PINE

p. 22

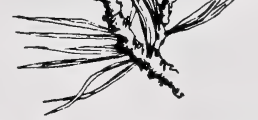

2. BUNDLES OF 2 NEEDLES, SPIRAL AND PROMINENTLY TWISTED:

\section{LODGEPOLE PINE}

p. 23

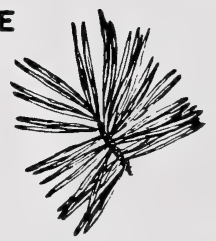




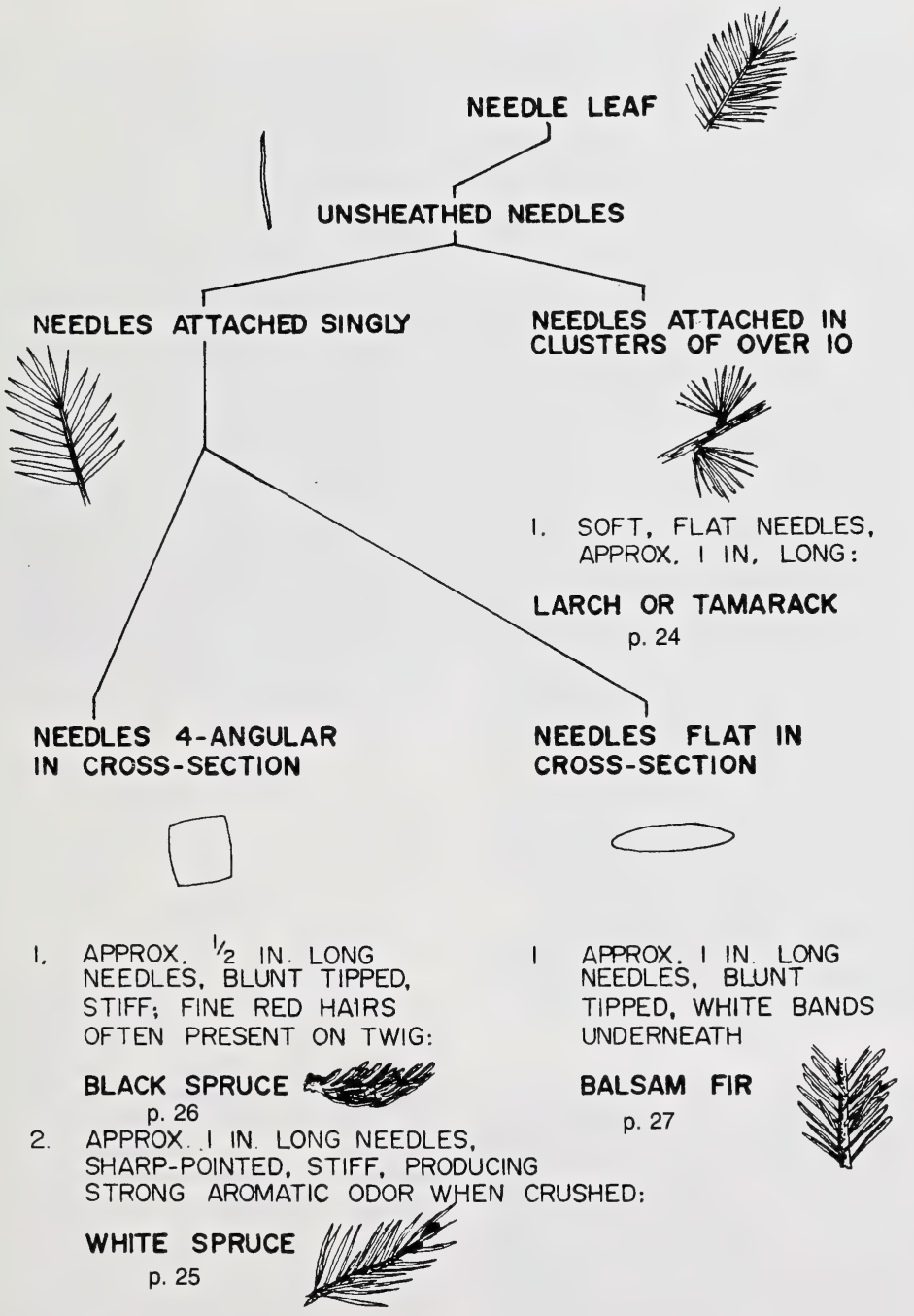




\section{Jack Pine}

Pinus banksiana Lamb.

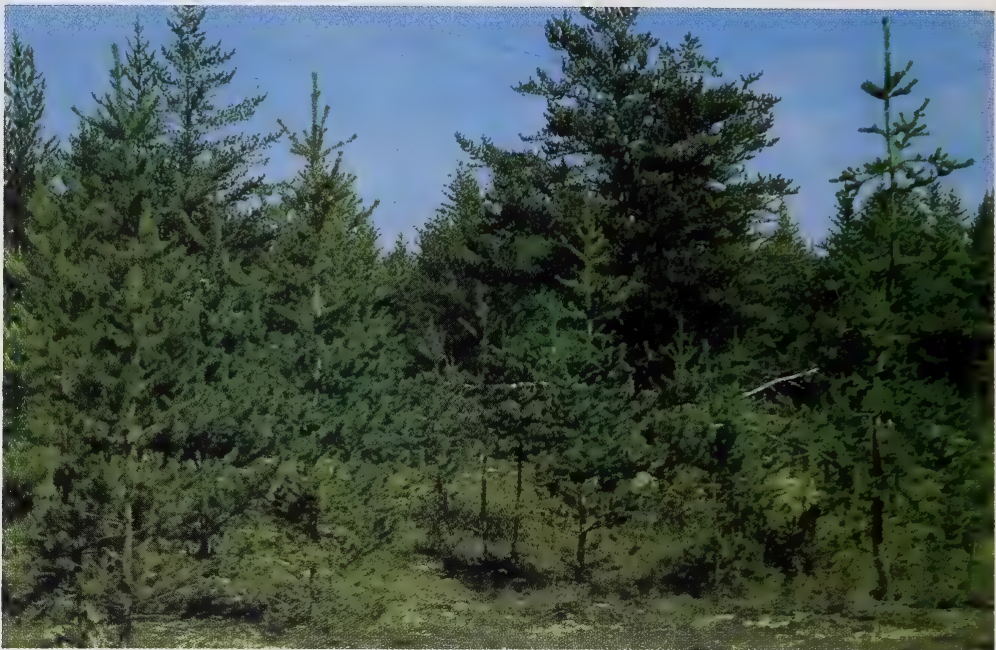

Photo by J. Hrapko

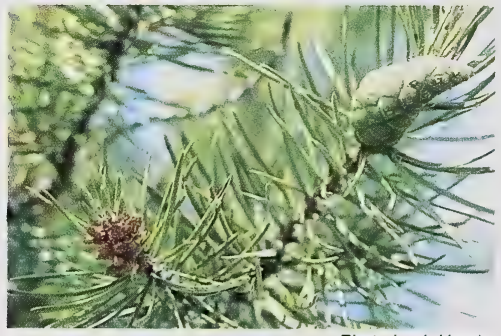

TREE: Small shrubby evergreen on open

Photo by J. Hrapko sites, somewhat taller in dense stands. Bark reddish-brown with irregular scaly ridges. Lower branches wide spreading. SIZE: 5-20 m (16-65 ft.) high; trunk 20$30 \mathrm{~cm}$ (8-12 in.) in diameter. LEAVES: Needle-shaped, in bundles of 2 , generally divergent, $2-5 \mathrm{~cm} \mathrm{(3/4-2}$ in.), yellowishgreen. CONES: Conical, 3-5 cm (1-2 in.) long, strongly incurved, generally in pairs, directed toward the tip of the branch, without prickles. DISTRIBUTION: Common on sandy and gravelly sites in central and northern Alberta. NOTES: Lodgepole Pine (P. contorta Loudon.) and Jack Pine hybridize freely where the ranges of these two species overlap in central Alberta. 


\section{Lodgepole Pine}

\section{Pinus contorta Loudon}

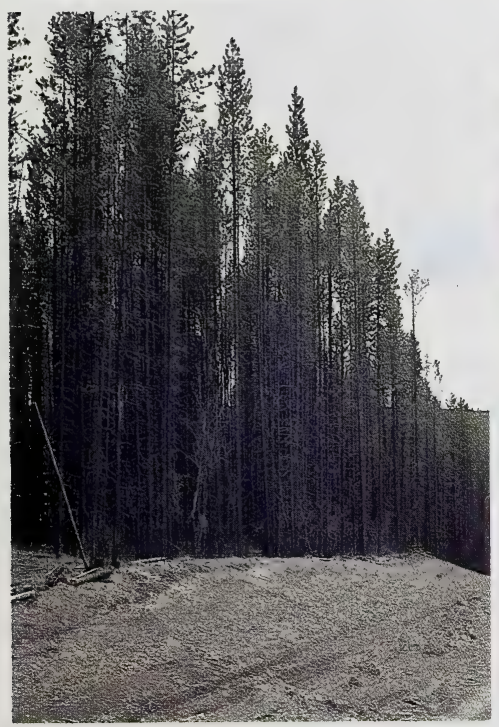

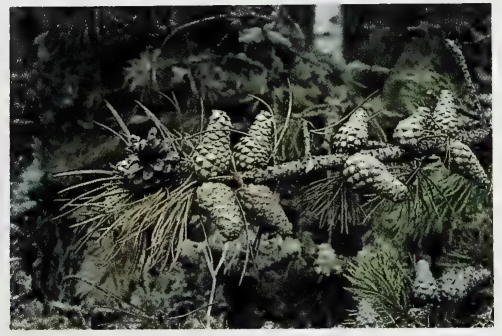

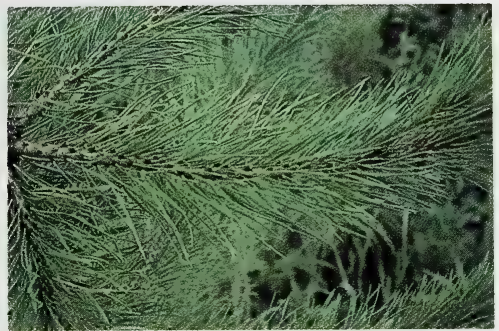

TREE: Tall, slender evergreen, with little taper and straight trunk. Bark orangebrown, somewhat scaly, less than $2 \mathrm{~cm}$ ( $1 / 2$ in.) thick. Branches curve upwards; self pruning in pure stands. SIZE: 20-30 $\mathrm{m}(65-100 \mathrm{ft}$.) high; trunk $30-45 \mathrm{~cm}$ (1218 in.) in diameter. LEAVES: Needleshaped, in bundles of two, $21 / 2-8 \mathrm{~cm}(1-3$ in.) long, spirally twisted, stiff, very sharp pointed, yellowish-green; form dense clusters toward the ends of twigs. CONES: Short-cylindrical to egg-shaped, curved away from branch tip, $2-5 \mathrm{~cm}$ (12 in.) long, remain on trees for many years; scales armed with small prickles. DISTRIBUTION: Grows on a wide variety of sites but prefers well drained sandy soils in the western part of the province. It is abundant in the Rocky Mountain and foothills regions. NOTES: Lodgepole Pine and Jack Pine (P. banksiana Lamb.) hybridize freely where the ranges of these two species overlap in central Alberta. As of May 1984, Lodgepole Pine is the official provincial tree of Alberta. 


\section{Tamarack}

Larix laricina (Du Roi) K. Koch

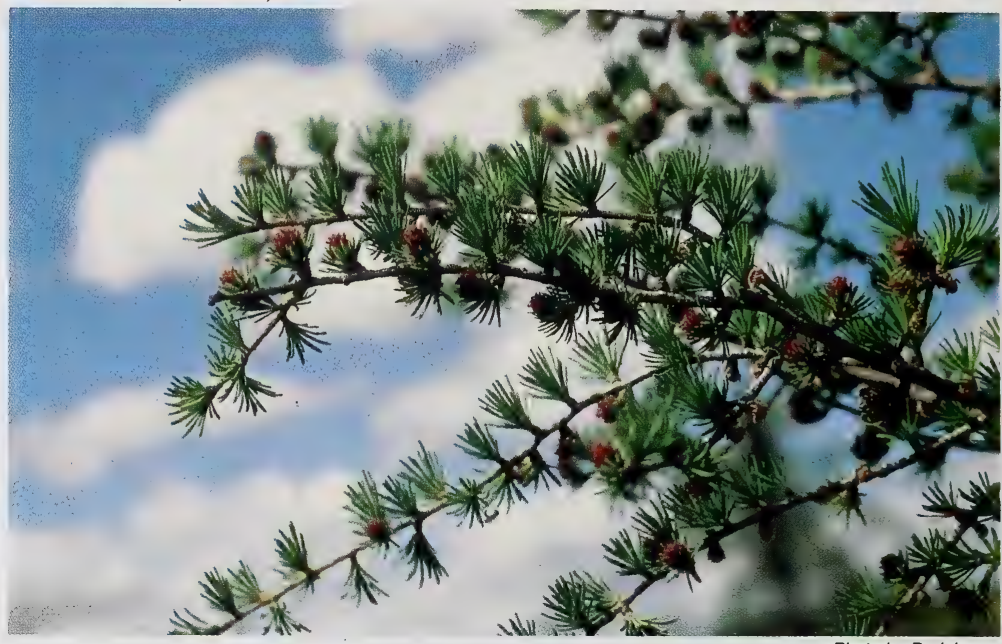

Photo by D. Johnson
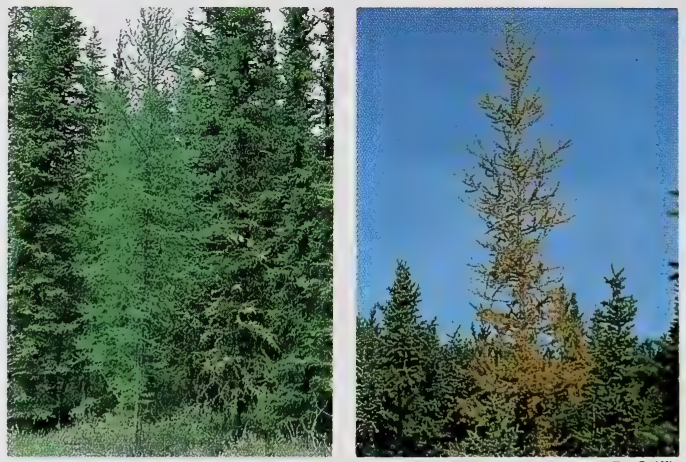

Photo by D. Griffin

TREE: Slender with a straight trunk having little taper. Bark thin, smooth, and grey when young becoming dark reddishbrown and scaly when older. Branches curved slightly downwards. SIZE: $20 \mathrm{~m}$ (65 ft.) high; trunk $30-60 \mathrm{~cm}(1-2 \mathrm{ft}$.) in diameter. LEAVES: Needle-shaped, in feather-like clusters of $10-20 ; 2-4 \mathrm{~cm} \mathrm{(3/4-}$ $1 \frac{1}{2}$ in.) long, soft, flexible; pale green turning bright yellow in autumn; shed in autumn. CONE: $2 \frac{1}{2} \mathrm{~cm}\left(1 \frac{1}{4}\right.$ in.) long, red- dish when young becoming brown when mature; open in the autumn and persist on tree through the winter and following summer. DISTRIBUTION: Found in muskeg or swamp areas in central and northern Alberta. In northern Alberta it can also be found on better drained sites such as valley slopes. NOTES: Lyall's or Subapline Larch (L. Iyallii Parl.) is found in the subalpine zone in the mountains, from Lake Louise to the Montana border. 


\section{White Spruce}

Picea glauca (Moench) Voss

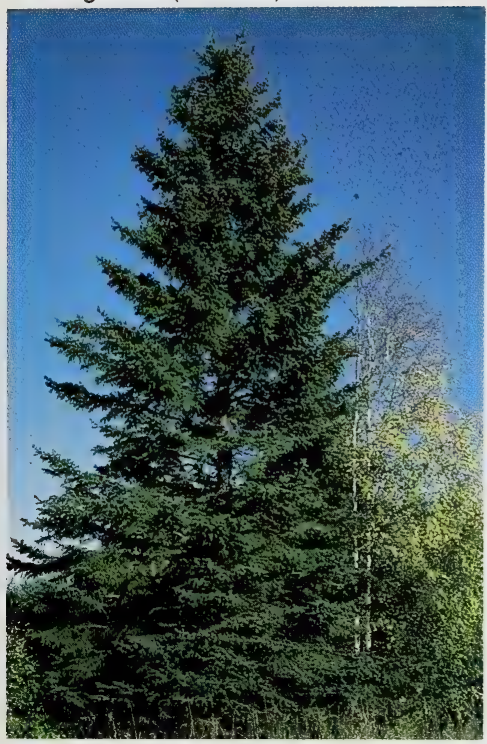

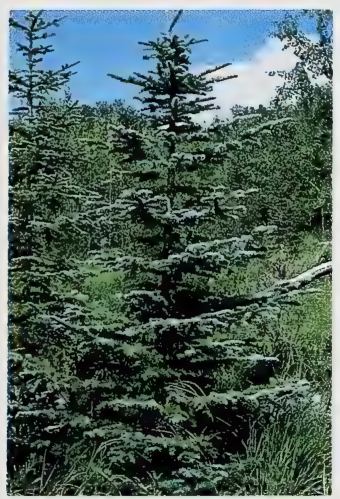

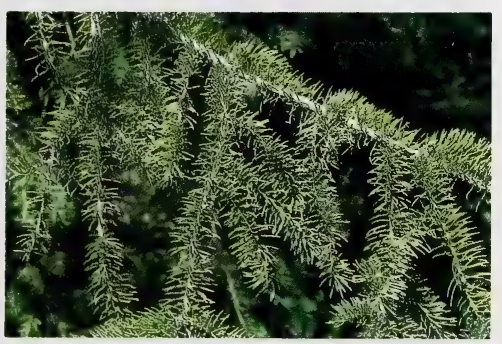

TREE: Dense evergreen with a straight, tapered trunk. Bark scaly, thin, grey to ashy-brown. Branches horizontal. SIZE: Averages $25 \mathrm{~m}$ (80 ft.) high; trunk $65 \mathrm{~cm}$ (2 ft.) in diameter. Under favorable conditions $40 \mathrm{~m}$ (130 ft.) high; trunk $130 \mathrm{~cm}$ $(4 \mathrm{ft}$.) in diameter. LEAVES: Needleshaped, 4-sided, 2-3 cm (1-11/4 in.) long, straight, stiff, sharp pointed, bluish-green; aromatic when crushed. CONES: Cylindrical, $4-5 \mathrm{~cm}\left(1 \frac{1}{2}-2 \mathrm{in}\right.$.) in length, located at the ends of twigs; yellow when young turning brown when mature, smooth margins. Cones open in the autumn and drop during the winter or spring. DISTRIBUTION: Common throughout western, central, and northern Alberta. It is found in a variety of soil types and climatic regions. 


\section{Black Spruce}

Picea mariana (Mill.) BSP.

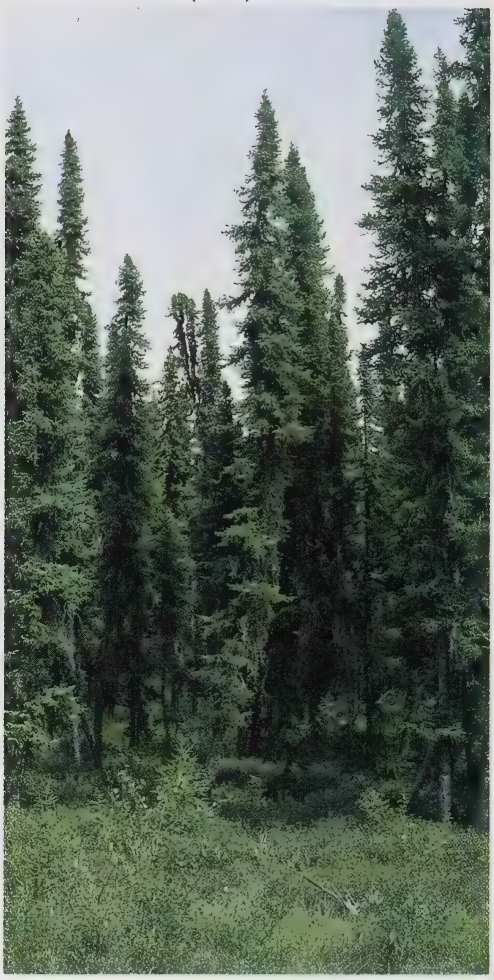

Bog Spruce, Swamp Spruce
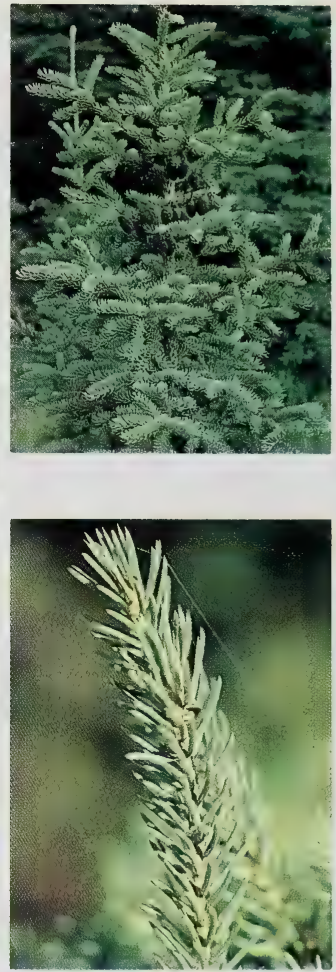

TREE: Dense evergreen with a straight trunk. Bark thin, greyish-brown and scaly. Branches upturned at ends forming a distinctive club-like shape at the crown. SIZE: Averages $10 \mathrm{~m}$ (35 ft.) high; trunk $25 \mathrm{~cm}$ (10 in.) in diameter. Under favorable conditions $30 \mathrm{~m}$ (100 ft.) high; trunk $92 \mathrm{~cm}$ (36 in.) in diameter. LEAVES: Needle-shaped, 4-sided, $1-2 \mathrm{~cm}(1 / 2-3 / 4$ in.) long; straight, thick, stiff, blunt, bluish green. CONES: Spherical, $2-3 \mathrm{~cm}(1 / 2-11 / 2$ in.) in length, purplish to dark brown; usually several in a cluster; retained for one or more years. DISTRIBUTION: Most common in swamp areas or muskegs throughout central and northern Alberta. 


\section{Balsam Fir}

Abies balsamea (L.) Mill.

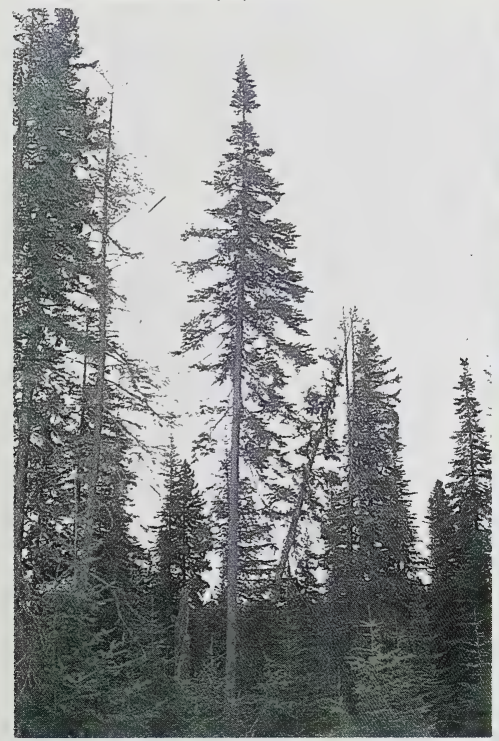

TREE: Symmetrical with narrow, conical crown. Bark smooth, pale grey and blistered on young trees, rough, scaly and brown on older trees. Branches horizontal. SIZE: $18 \mathrm{~m}$ (60 ft.) high; trunk $45 \mathrm{~cm}$ $\left(1 \frac{1}{2} \mathrm{ft}\right.$.) in diameter. LEAVES: Needleshaped, flattened, $2-3 \mathrm{~cm}\left(3 / 4-1 \frac{11 / 4}{}\right.$ in.) long, bent upward, rounded or blunt tipped; dark shiny green surface and whitish underside. CONES: Oval or oblong, 5-10 cm (2-4 in.) long, dark purple; disintegrate on tree and do not fall. DISTRIBUTION: Common tree in northeastern Alberta which has adapted to a variety of soils and climates. NOTES: Subalpine Fir (A. lasiocarpa (Hook.) Nutt.), a mountain species, is similar in appearance to Balsam Fir. It is larger, 25 $\mathrm{m}(76 \mathrm{ft}$.) high, and its leaves are greyishgreen to pale blue-green. Subalpine Fir is mainly distinguishable from Balsam Fir by slight differences in their cones.
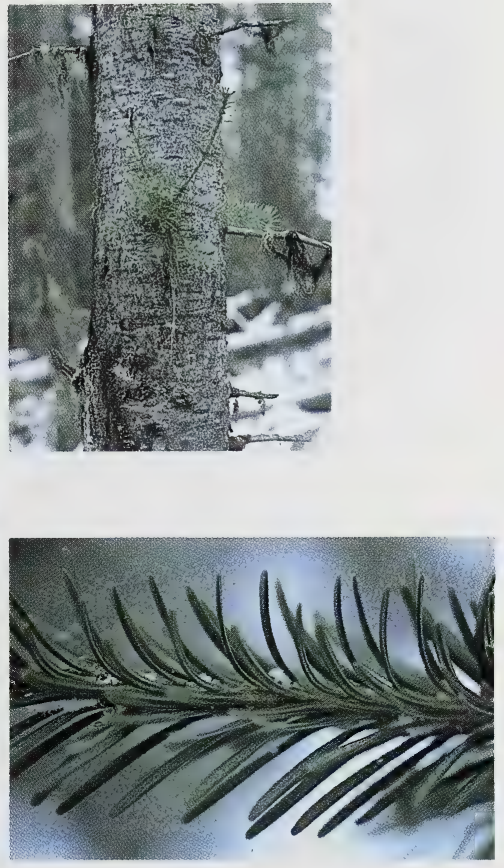


\section{Willows}

Salix L.
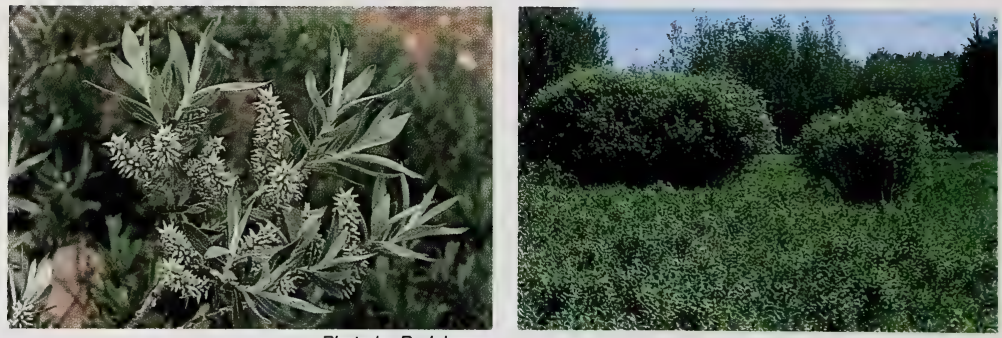

Photo by D. Johnson
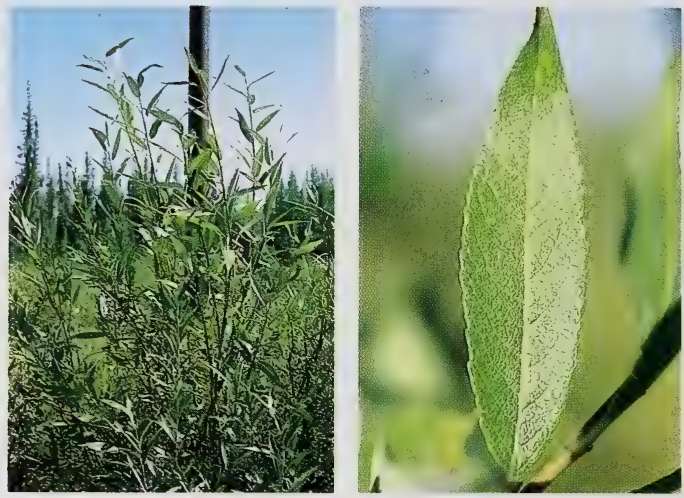

SHRUBS-SMALL TREES: Variable in size and form, many branches; bark yellowish-brown to reddish-brown to grey, smooth or scaly. SIZE: $1-9 \mathrm{~m}$ (3-30 ft.) high. LEAVES: Alternate, simple, long and narrow, pointed at both ends; most species have small fine teeth on margins. FLOWERS: Greenish female (seed) catkins; yellowish male (pollen) catkins. FRUIT: Capsules in catkins. DISTRIBUTION: Willows are sun loving and are found throughout Alberta, mainly along the edges of lakes, rivers and in wetter areas. Among the many species in Alberta, common ones are: BEAKED WILLOW (S. bebbiana Sarg.) - 1-4 m (3-12 ft.) high; slender, reddish-brown branches; leaves $2-5 \mathrm{~cm}$ (1-2 in.) long, 1 $2 \mathrm{~cm}\left(1 / 2^{-3 / 4} \mathrm{in}\right.$.) wide; $6 \mathrm{~cm}\left(2 \frac{1}{2}\right.$ in.) long catkins, which appear shortly before or at

the same time as the leaves. HOARY WILLOW: (S. candida Fluegge ex Willd.) - 1-2 m (3-6 ft.) high; slender branches with white woolly twigs; leaves, 4-7 cm $(13 / 4-23 / 4$ in.) long, hairy underside; catkins appear the same time as leaves. PUSSY WILLOW: (S. discolor Muhl.) - 2-5 m (6$16 \mathrm{ft}$.) high; slender reddish-brown branches, greyish-brown stems; leaves $5-8 \mathrm{~cm}(2-3 \mathrm{in}$.) long, $2-4 \mathrm{~cm} \mathrm{(3/4-11/4}$ in.) wide, shiny green upper surface, paler underside; catkins appear before leaves. SANDBAR WILLOW (S. exigua Nutt.) 1-4 m (3-13 ft.) high; greyish-brown stems and branches; leaves variable $3-15 \mathrm{~cm}$ (11/4-6 in.) long, 3-15 m (1/8-1/2 in.) wide, shiny dark green surface, pale green underside; catkins $2-6 \mathrm{~cm}(3 / 4-21 / 2$ in.) long, appear same time as leaves. 


\section{Aspen Poplar}

Populus tremuloides Michx.

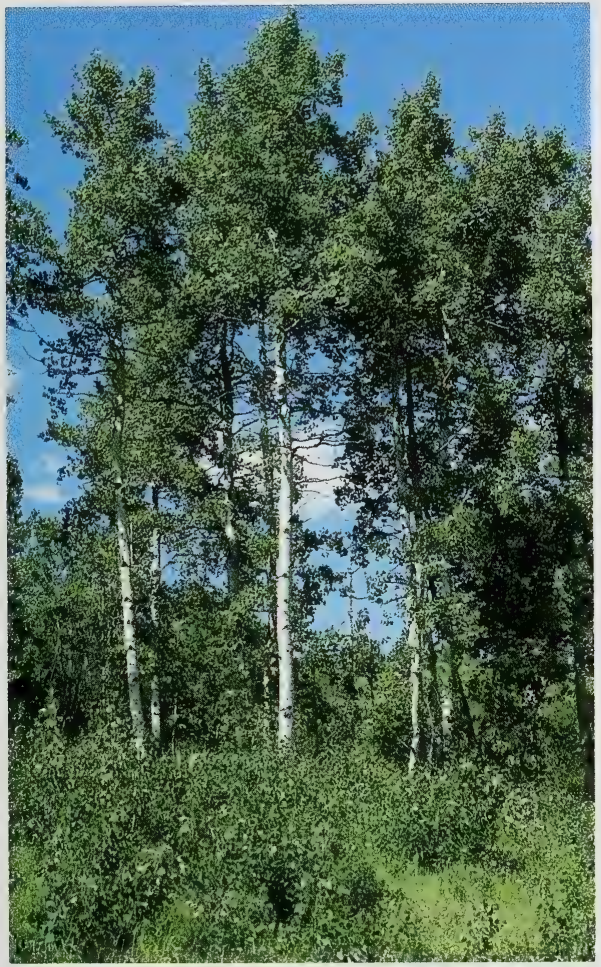

Trembling Aspen, White Poplar
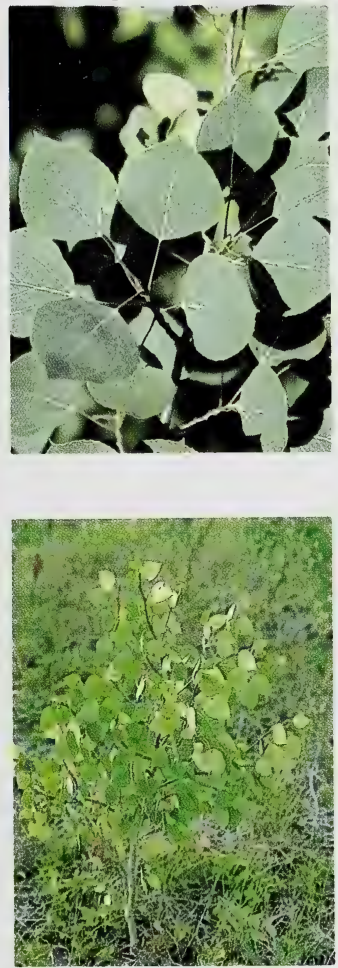

TREE: Slender with a long straight trunk and rounded crown. Bark smooth, greenish-white on young trees becoming somewhat blackened and furrowed near base on older trees. Branches restricted to tops on mature trees. SIZE: Averages $20 \mathrm{~m}$ (65 ft.) high; trunk $25 \mathrm{~cm}$ (10 in.) in diameter. Under favorable conditions 30 $\mathrm{m}$ (95 ft.) high; trunk $61 \mathrm{~cm}(2 \mathrm{ft}$.) in diameter. LEAVES: Alternate, simple, oval to ovate, 4-6 cm $\left(1 \frac{1}{2}-2 \frac{1}{2} 2\right.$ in.) wide; fine, irregular, rounded teeth on margin; slender, flattened petiole, usually longer than the leaf-blade; deep green upper surface, paler underside. FLOWERS: Small, hairy, drooping catkins appear before the leaves. FRUIT: Small, green capsules splitting when ripe to form a cotton mass. DISTRIBUTION: Very common and widespread throughout forested regions, but grows best in well drained soils. NOTES: Leaves tremble with slight breezes because of flattened leaf petioles. This tree suckers freely when cut or damaged. Root suckering is the primary method of propagation. 


\section{Balsam Poplar}

Populus balsamifera L.
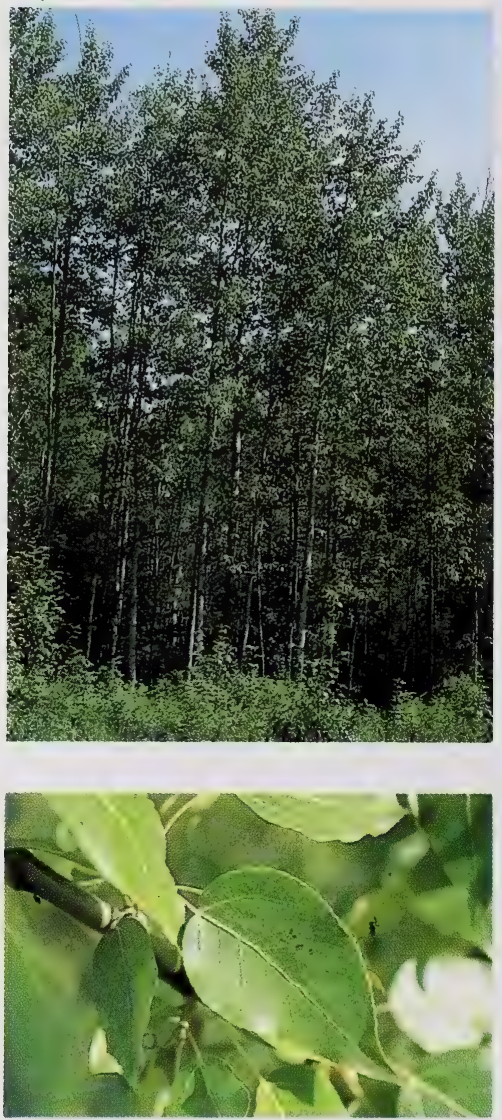

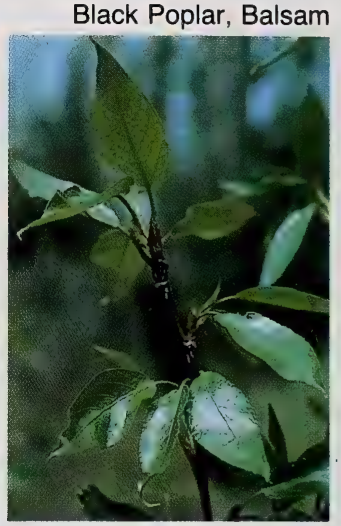

TREE: Slender, with a long, straight, trunk and narrow crown. Bark light grey and smooth on young trees, dark grey and furrowed on mature trees. Branches stout, pointing upward. SIZE: Averages $20 \mathrm{~m}$ (65 ft.) high; trunk $40 \mathrm{~cm}$ (16 in.) in diameter. Under favorable conditions 30 $\mathrm{m}$ (100 ft.) high; trunk $120 \mathrm{~cm}(4 \mathrm{ft}$.) in diameter. LEAVES: Alternate, simple, ovate to ovatelanceolate, $8-15 \mathrm{~cm}$ (3-6 in.) long; fine, irregular, rounded teeth on margin; shiny dark green surface, with whitish-green underside sometimes with rusty brown resin stains; winter buds large and pointed and covered with sticky resin. FLOWERS: Small, drooping catkins, appear before the leaves. FRUIT: Small, green capsules splitting when ripe to form large amounts of loose cotton mass that is blown about by spring breezes. DISTRIBUTION: Common and widespread throughout most of Alberta but grows best on rich, moist soils and low lying terrain. NOTES: A similar species, called Black Cottonwood ( $P$. trichocarpa Hook.), is found in the western parts of the province. It is very difficult to differentiate from Balsam Poplar because both species hybridize freely. Balsam Poplar readily suckers when the main trunk is cut or damaged. 


\section{Beaked Hazelnut}

\section{Corylus cornuta Marsh.}

Beaked Hazel, Beaked Filbert

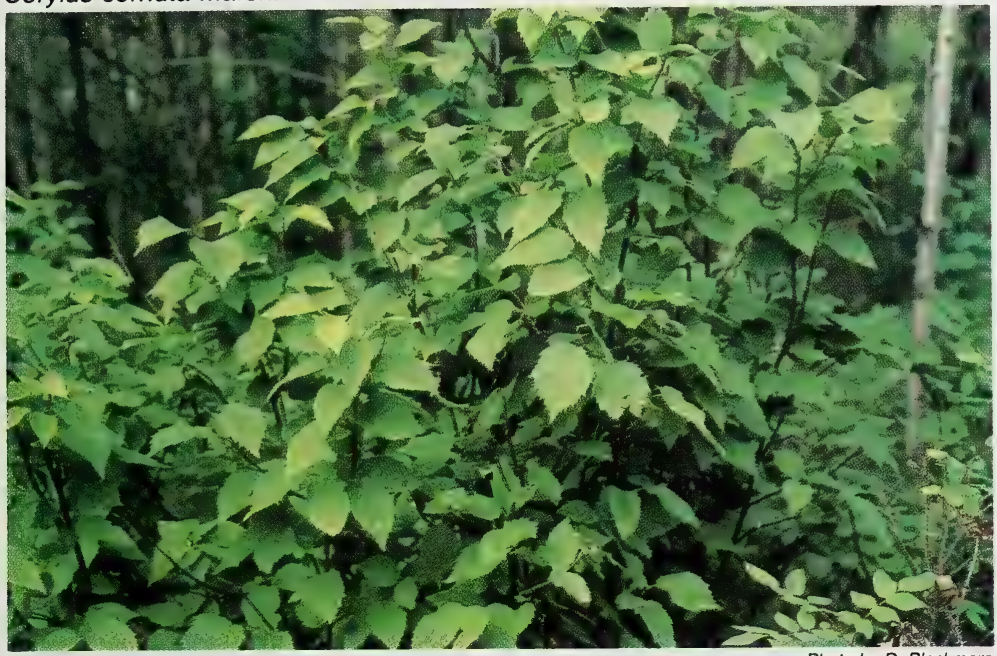

Photo by D. Blackmore
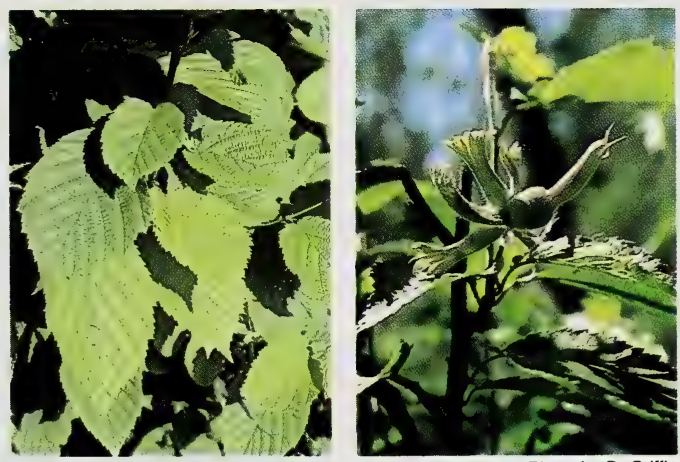

Photo by D. Griffin

SHRUB: Comprised of many slender erect stems with numerous branches. Bark rough, light brown. SIZE: 1-3 m (3$10 \mathrm{ft}$.) high. LEAVES: Alternate, simple, ovate, gradually tapering to a point, $5-20$ cm (2-4 in.) long, coarsely-toothed margins; dull green surface, with paler underside, hairy along veins. FLOWERS: Small, hanging, yellow male catkins and tiny reddish female flowers on the branch tips above; appear in spring before the leaves. FRUIT: A nut, enclosed in two rough-hairy green bracts, which extend beyond nut to form a beak. DISTRIBUTION: Found in central and northern parts of the province. It grows well in open areas or in the shade and prefers welldrained sites. 


\section{White Birch}

Betula papyrifera Marsh.

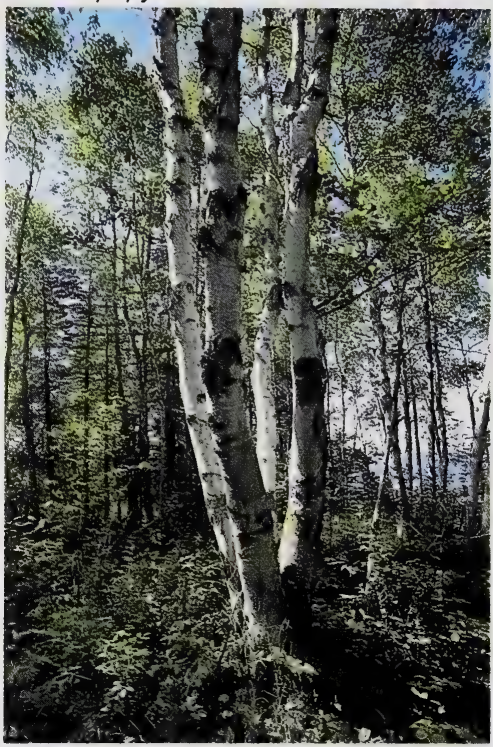

Photo by Alberta Forest Service

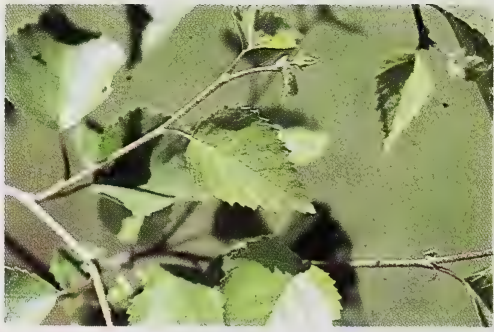

Paper Birch, Canoe Birch

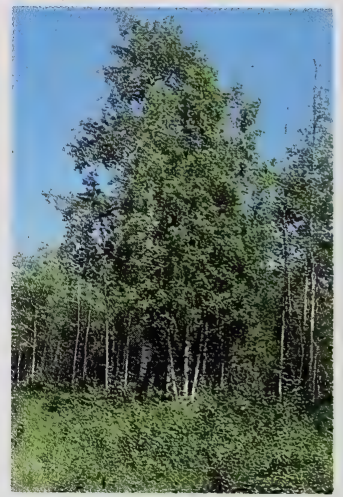

TREE: Small to medium sized. Crown oval when associated with other trees and pyramidal in the open. Branches slender, twisted, pebbled, reddish-brown. Bark smooth, reddish-brown turning white with age, peels easily. SIZE: Averages 6-15 m (20-50 ft.) high; trunk 20-30 cm (8-13 in.) in diameter. Under favorable conditions $18-25 \mathrm{~m}$ (60-80 ft.) high; trunk $40-50 \mathrm{~cm}$ (16-20 in.) in diameter. LEAVES: Alternate, simple, ovate, tapering to a sharp point; $2-9 \mathrm{~cm}(3 / 4-31 / 2$ in.) long; margins saw-toothed except near the base; dull green surface with paler, slightly hairy underside. FLOWER: Drooping, greenish-brown catkins. FRUIT: Cone-like catkins, $2-4 \mathrm{~cm}(1 / 2-11 / 2$ in.) long, $1 \mathrm{~cm}(1 / 2 \mathrm{in}$.) in diameter. DISTRIBUTION: Common along riverbanks and moist, wooded areas throughout Alberta. Prominent in the forested regions in the central and northern parts of the province. 


\section{Swamp Birch}

Betula pumila L.

Bog Birch, Dwarf Birch
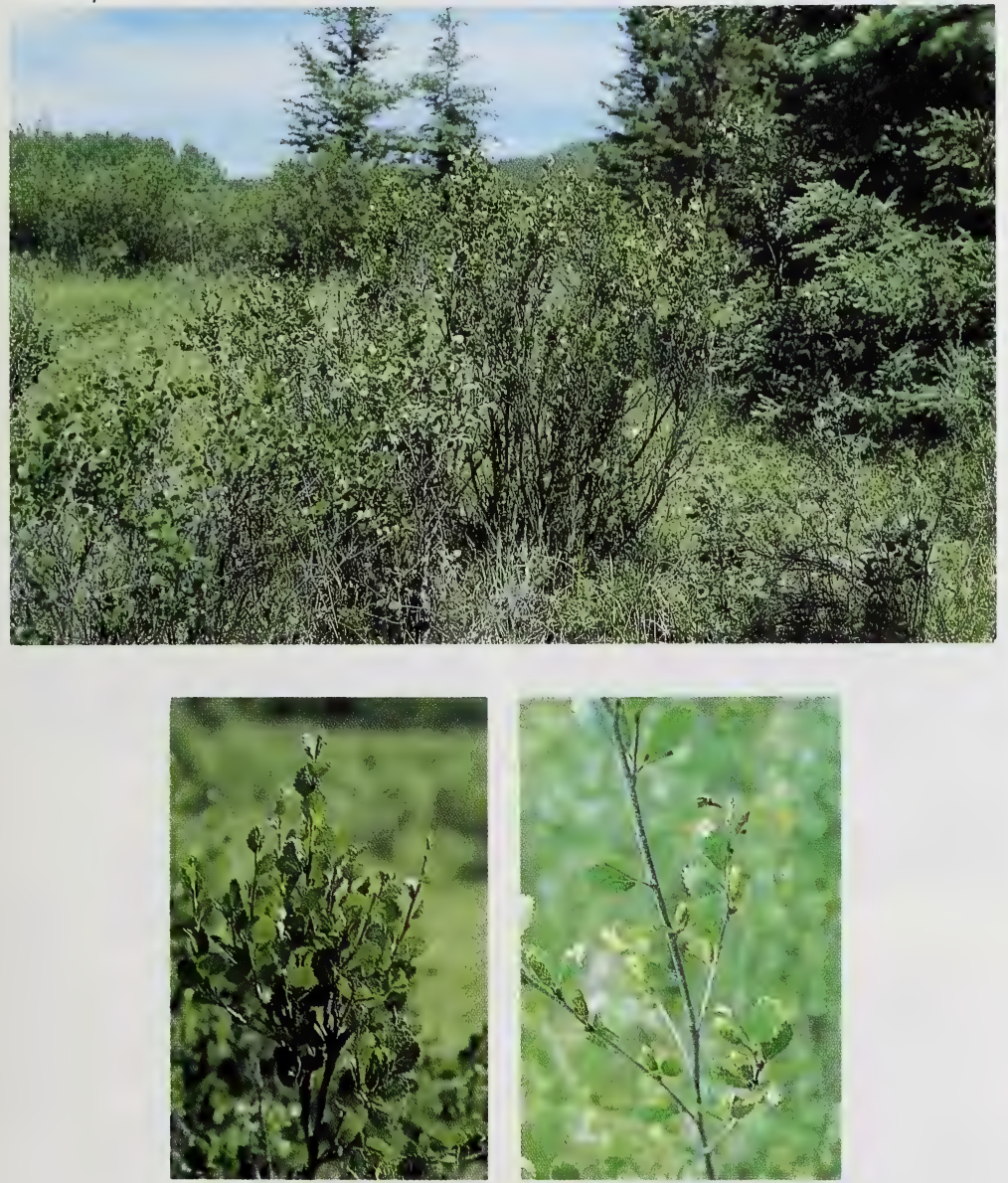

SHRUB: Bushy with many branches, erect or low spreading, densely covered with leaves and wart-like resinousglands. SIZE: 1-2 m (3-7 ft.) high. LEAVES: Alternate, simple, obovate, 2-3 $\mathrm{cm}\left(3 / 4-1 \frac{1 / 4}{4}\right.$ in.) long; rounded teeth on margins; dark green and shiny surface, light green underside; young leaves have fine hairs underneath. FLOWERS: Slightly hairy catkins, appear in spring, 2$3 \mathrm{~cm}\left(3 / 4-1 \frac{1}{4}\right.$ in.) long. FRUIT: Brown, cone-shaped catkins containing small winged nutlets. DISTRIBUTION: Common around bogs and swampy areas in forested regions of the province. 


\section{Green Alder}

Alnus crispa (Ait.) Pursh.

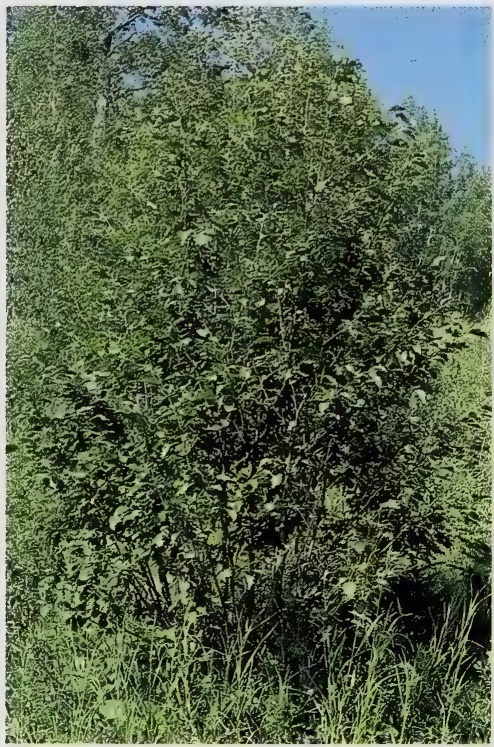

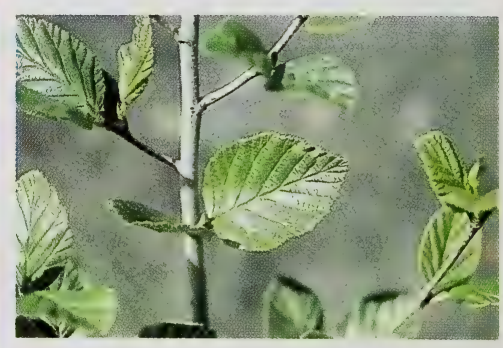

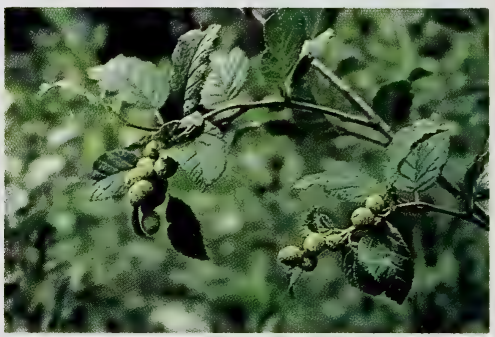

Photo by D. Blackmore

SHRUB: Bushy, with upward curving branches. Bark smooth, reddish-brown or grey. Stems and twigs covered with white dots. SIZE: 1-3 m (3-10 ft.) high. LEAVES: Alternate, simple, ovate, 2-8 cm (1-3 in.) long; fine, sharp double toothed margins; prominent veins, shiny green surface, paler underside; sticky when young. FLOWERS: Light green catkins which develop before the leaf buds open; female catkins $1-1 \frac{1}{2} \mathrm{~cm}\left(1 / 2^{-3 / 4}\right.$ in.) long; male catkins $7-13 \mathrm{~cm}$ (3-5 in.) long. FRUIT: Small, cone-like catkins on long stalks; several in a cluster; green turning brown and woody at maturity; nutlets with wings. NOTES: The River Alder (A. tenuifolia Nutt.) and the Speckled Alder ( $A$. rugosa (Du Roi) Spreng.) are closely related to the Green Alder and are also found in Alberta. The River and Speckled Alder can grow up to $6 \mathrm{~m}$ (20 ft.) high, and have slightly different leaf margins. 


\section{Wild Gooseberry}

Ribes oxyacanthoides $\mathrm{L}$.

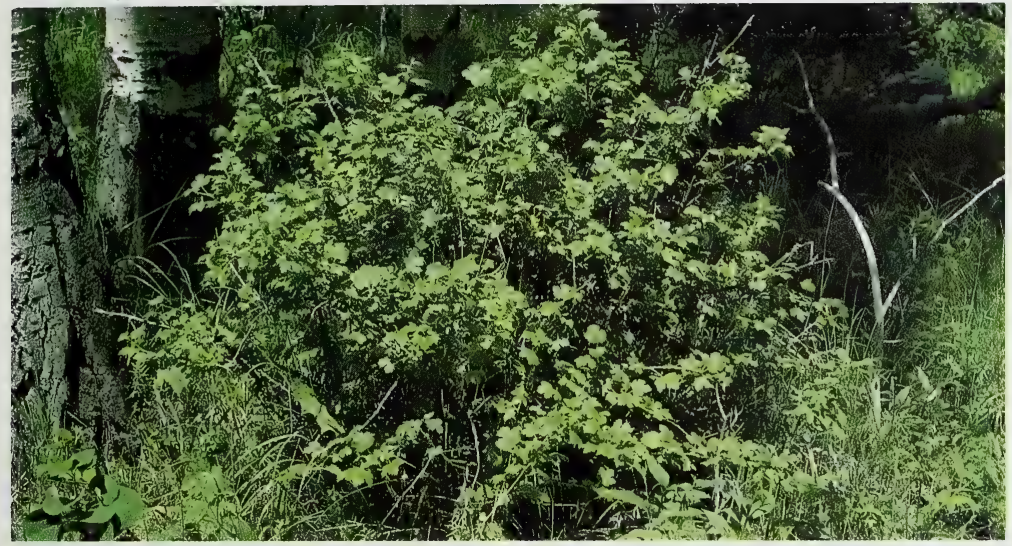

SHRUB: Small, erect, several stems originating from root collar. New growth bright green, covered with numerous bristles. Old growth yellowish-grey. Sharp spines at base of leaves. SIZE: $3 / 4-11 / 4 \mathrm{~m}(2-4 \mathrm{ft}$.) high. LEAVES: Alternate, simple, 3-5 lobes, $3-5 \mathrm{~cm}\left(1 \frac{11 / 4-2}{\mathrm{in}}\right.$.) long; round toothed margins; light green surface, lighter hairy underside. FLOWERS: Greenish-white, small, bell-shaped; single or in clusters. FRUIT: Round berry, with white stripes; light green turning reddish-purple with age. DISTRIBUTION: Wild Gooseberry is found throughout Alberta and prefers to grow in openings on moist rich soil. NOTES: Northern Gooseberry ( $R$. Lirtellum Michx.) differs from Wild Gooseberry in that it does not have bristles on the stem and is only found in northern and central Alberta. Many currants and gooseberries are similar in appearance to the Wild Gooseberry. Generally currants, such as Wild Red Currant ( $R$. triste Pall.), have unarmed stems while gooseberries are

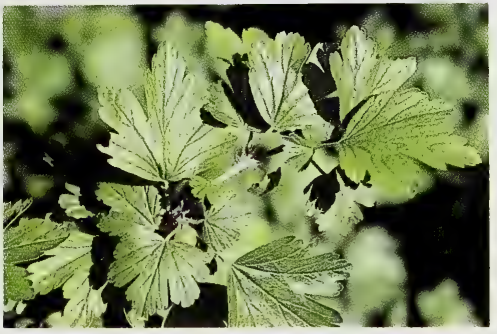
armed.

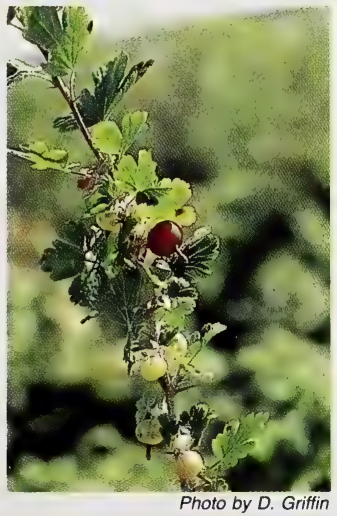




\section{Saskatoon}

Amelanchier alnifolia Nutt.

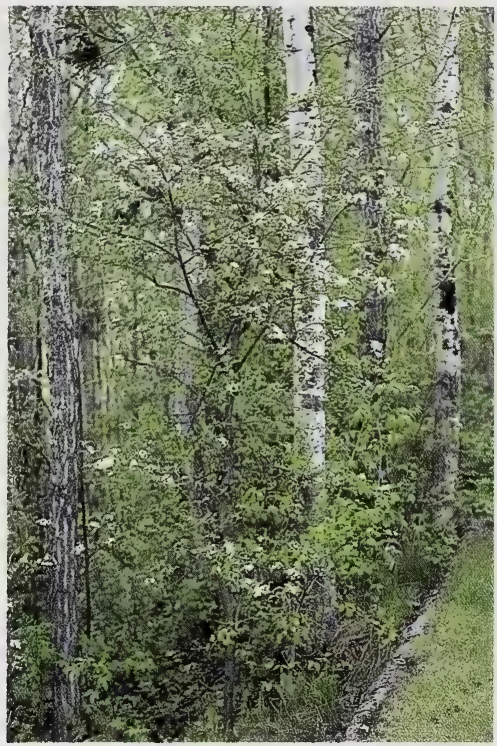

Saskatoon-berry, June-berry, Serviceberry, Shedbush
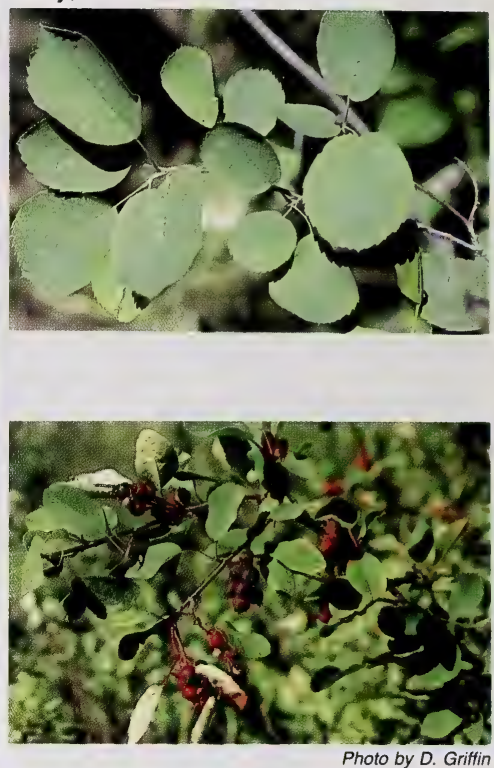

SHRUB: Tall, somewhat slender, may be dwarfed or misshaped. Bark smooth, greyish-brown. SIZE: Averages 1-3 m (3$10 \mathrm{ft}$.) high; under favorable conditions 4$6 \mathrm{~m}$ (13-20 ft.) high. LEAVES: Alternate, simple, small, oval, with rounded tips; 1 $5 \mathrm{~cm}(1 / 2-2 \mathrm{in}$.) long; bluish-green in color; coarse teeth on margin especially near tip; many fine hairs on the underside of new leaves, becoming smooth and hairless with age. FLOWER: White, with five petals; $1 \mathrm{~cm}(1 / 2 \mathrm{in}$.) in diameter; in dense terminal clusters. FRUIT: Berry-like, $1 \mathrm{~cm}$ $(1 / 2$ in.) in diameter; blue to dark purple when ripe; in clusters at end of branch. DISTRIBUTION: Found in open woods, bluffs, along the edge of forest, stream banks and along roadsides. This plant prefers dry sites and good exposure to the sun. It is commonly found throughout Alberta. Colonies are sometimes formed because of its ability to sucker. 


\section{Shrubby Cinquefoil}

Potentilla fruticosa $\mathrm{L}$.

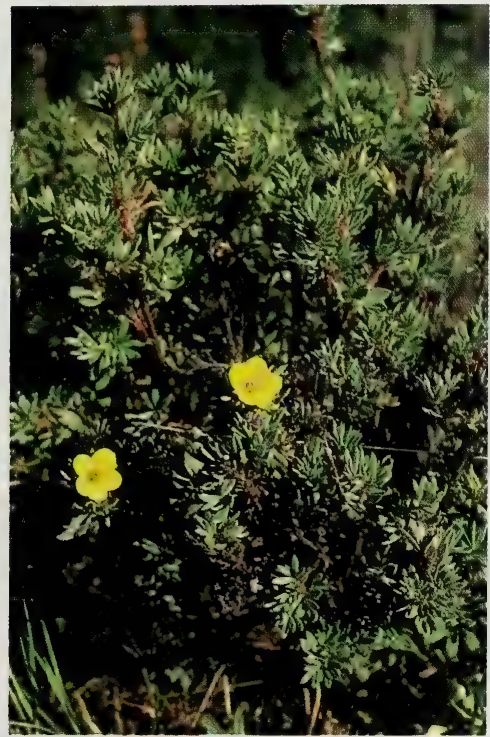

Photo by D. Griffin
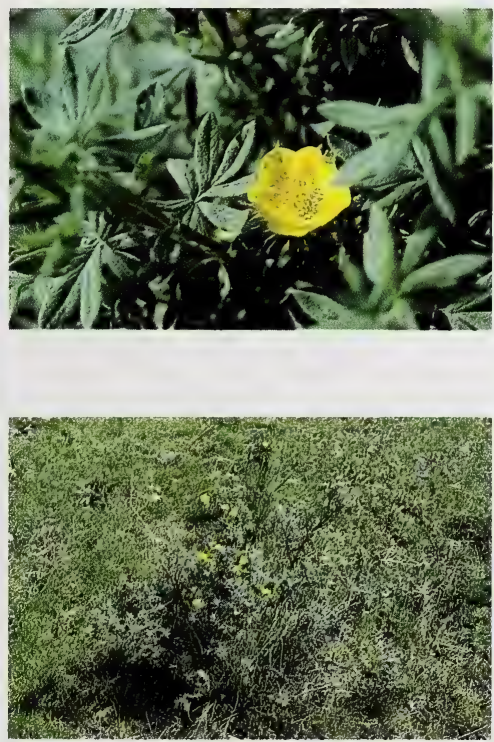

SHRUB: Low growing with many bushy branches. Bark is rough and shredded, particularly on older branches. SIZE: $1 / 2-$ $1 \mathrm{~m}$ (1-3 ft.) high. LEAVES: Alternate, compound, composed of 5-7 grey-green leaflets; each leaflet approximately $2 \mathrm{~cm}$ $(3 / 4$ in.) long; smooth margins, oblong, with a velvet-like texture. FLOWERS:

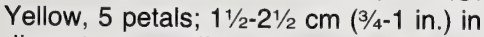
diameter, usually in clusters at each branch tip. FRUIT: Seeds covered by fine straight white hairs. DISTRIBUTION: This plant is most commonly found in Alberta's grassland and foothill regions, but is also present in other parts of the province. In the forest it prefers poorly drained sites. 


\section{Pin Cherry}

Prunus pensylvanica L.f.

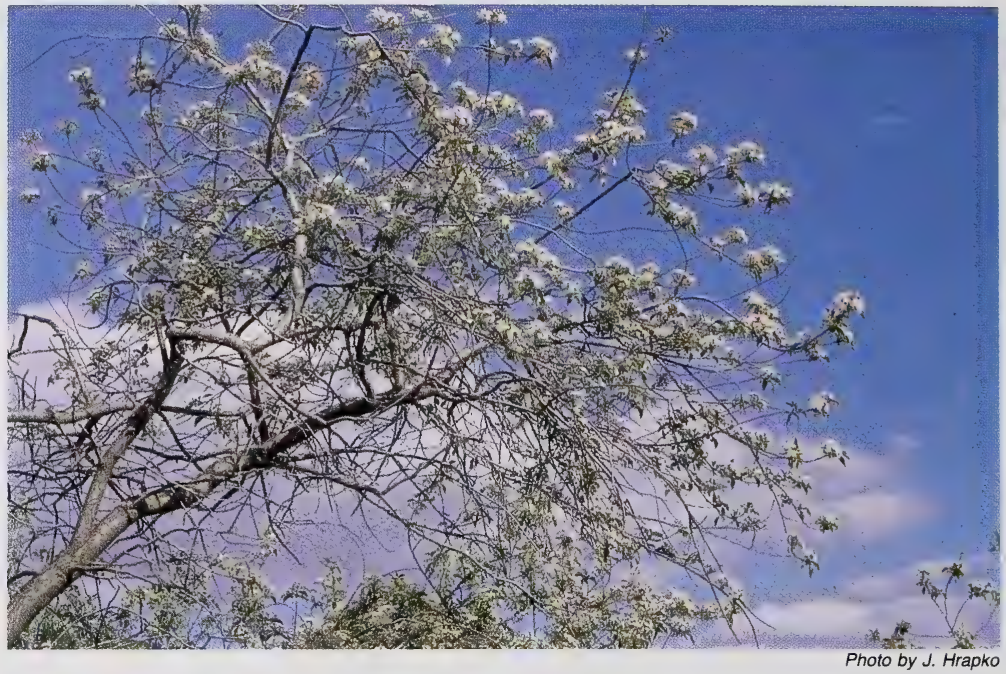

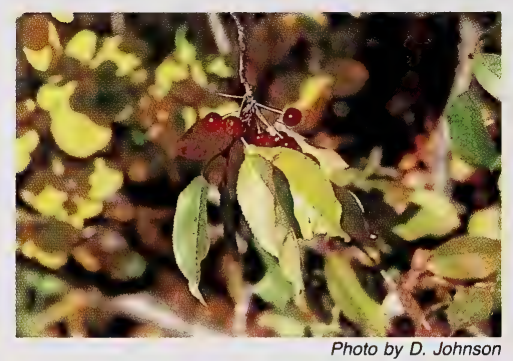

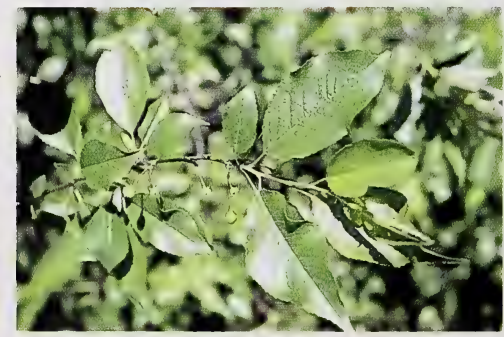

SHRUB OR SMALL TREE: Fairly straight, with narrow rounded crown. Branches point upwards. Bark reddishbrown, smooth on young trees, marked by orange, horizontal dots on older trees. SIZE: $3-8 \mathrm{~m}$ (10-25 ft.) high. LEAVES: Alternate, simple, ovate, with sharp pointed tip; $5-12 \mathrm{~cm}$ (2-5 in.) long; petioles red; fine, uneven teeth on margins; shiny dark green surface, pale green underside. FLOWERS: White, small $1 / 2-1 \mathrm{~cm}(1 / 4-3 / 8$ in. $)$ in diameter; in clusters, each on a long stalk; appear the same time as leaves. FRUIT: Small, round, bright red cherry, each on a single pin-like stem. DISTRIBUTION: Found in open woods, bluffs, and along river banks throughout Alberta. It is intolerant of shade and, therefore, is seldom found in mature forests. 


\section{Choke Cherry}

\section{Prunus virginiana $\mathrm{L}$.}

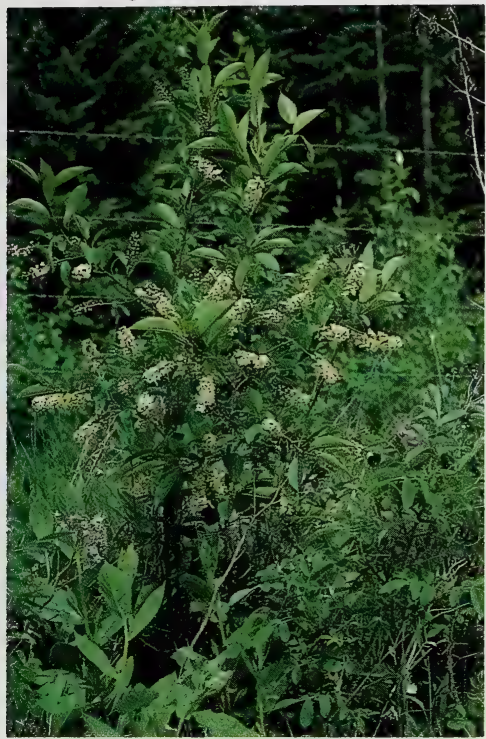

SHRUB OR SMALL TREE: Irregularly shaped, with a slender, twisted trunk. Crown narrow and irregular and composed of crooked, spreading branches. Bark smooth, reddish-brown turning black on older growth. SIZE: 2-8 m (6-25 ft.) high. LEAVES: Alternate, simple, ovate, with a sharp point; $2-8 \mathrm{~cm}$ (1-3 in.) long; finely toothed along margins; dark green surface, paler green underside; thick and leathery. FLOWERS: Creamywhite, small, $1-1 \frac{1}{2} \mathrm{~cm}(1 / 2-3 / 4$ in. $)$ in diameter; form dense, cylindrical clusters at ends of twigs. FRUIT: Small, round, deep red to dark purple, $6-8 \mathrm{~mm}(1 / 4-1 / 3 \mathrm{in}$.) in diameter; form clusters with common stem. DISTRIBUTION: Common in bluffs, ravines, open areas, and along river banks and roadsides throughout Alberta. Can tolerate very dry conditions on the prairies. NOTES: The underground root system suckers freely.

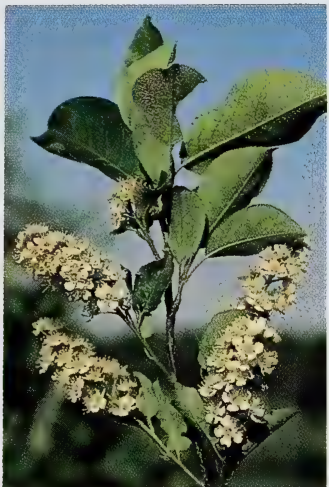

Photo by D. Griffin

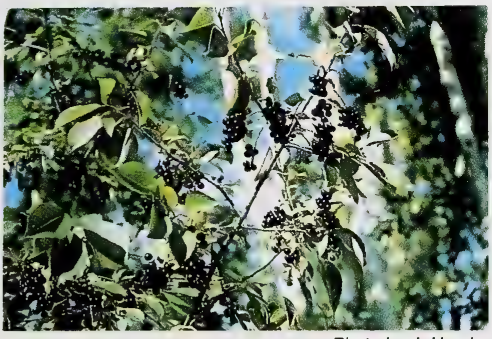

Photo by J. Hrapko 


\section{Prickly Wild Rose}

Rosa acicularis Lindl.

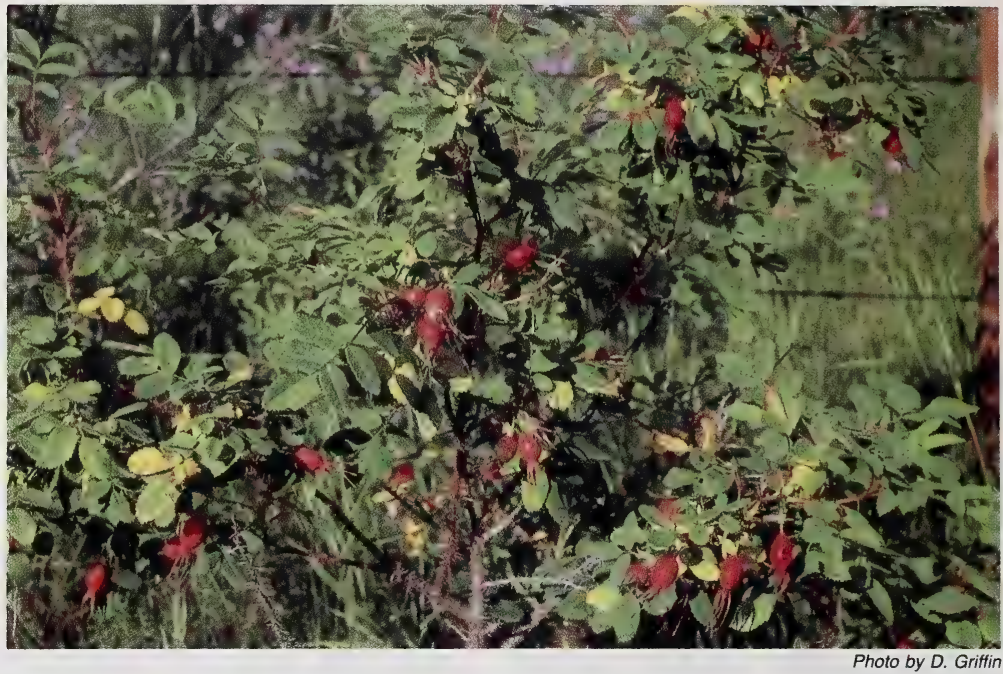

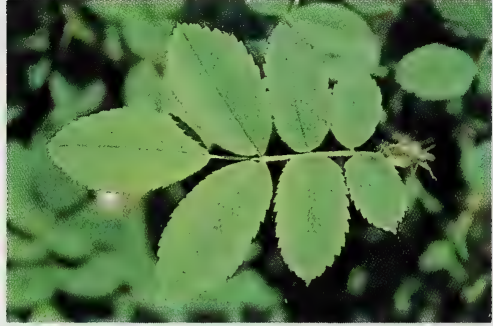

Photo by J. Hrapko

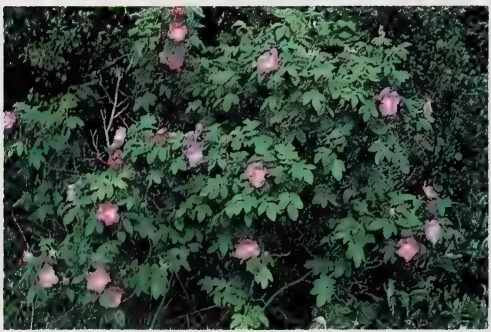

SHRUB: Bushy, with straight, weak prickles densely covering the branches to the tips of new growth. SIZE: $1 / 4-1 \mathrm{~m}(1-31 / 2$ ft.) high. LEAVES: Alternate, compound, oval, with 5 to 7 leaflets per stem; leaflets $1-5 \mathrm{~cm}(1 / 2-2$ in.) long, coarse teeth along margins; dark green surface with paler hairy underside. FLOWERS: Pink, with 5 petals; $5-7 \mathrm{~cm}$ (2-3 in.) in diameter. FRUIT: Rose hips; oval, bright red to orange, about $2 \mathrm{~cm}(3 / 4 \mathrm{in}$.) long. DISTRIBUTION: Common in or at edges of open forests and along roadways and waterways throughout the province, except the southeastern prairie. NOTES: The Prickly Wild Rose is Alberta's floral emblem. However, two other rose species are commonly found in Alberta: Common Wild Rose (R. woodsii Lindl.) and Prairie Rose (R. arkansana Porter). These species are similar in appearance to the Prickly Wild Rose. 


\section{Wild Red Raspberry}

Rubus idaeus L.

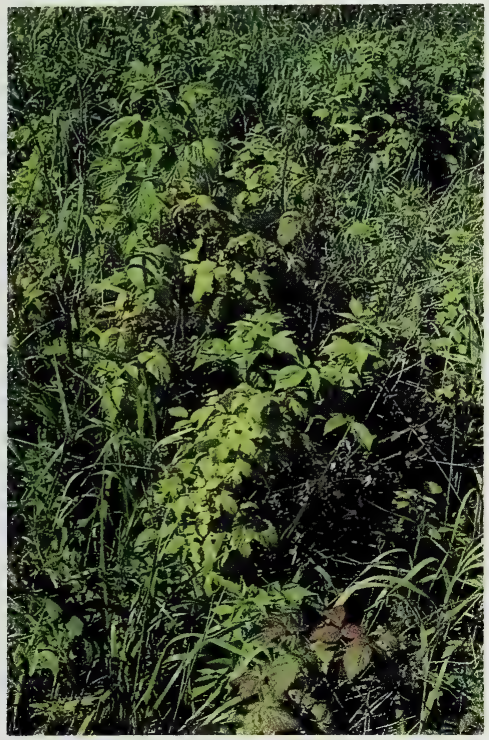

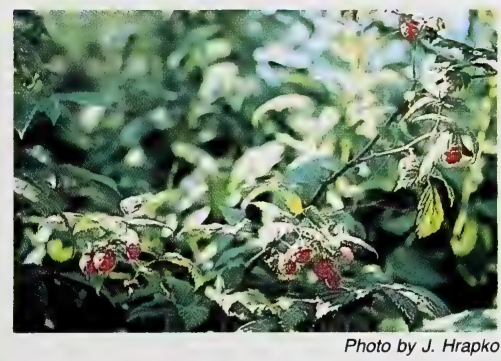

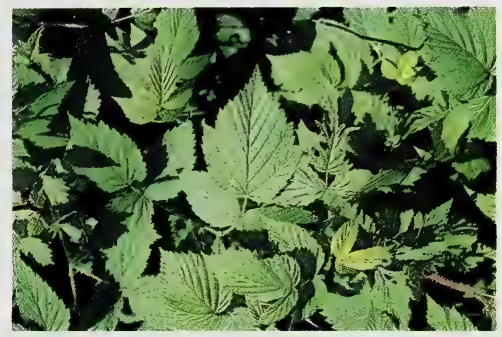

SHRUB: Pronounced main stem covered with prickles. Bark reddish-brown. SIZE: 1-2 m (3-6 ft.) high. LEAVES: Alternate, compound, with 3-5 ovate leaflets; leaflets $5-10 \mathrm{~cm}$ (2-4 in.) long; crinkly, deeply toothed along margins; dark green surface with paler, hairy underside. FLOWERS: White, with 5 petals; 8-12 mm (1/3$1 / 2$ in.) in diameter, attached to a hairy stalk. FRUIT: Red, round, juicy, edible, compound berry composed of many small sections; lumpy in appearance. DISTRIBUTION: This plant grows well in cleared areas, in borders around wooded areas and along riverbanks and roadways throughout Alberta. It is tolerant of some shade. If the stem tips become buried, roots will develop and another shrub will grow. NOTES: There are other less common raspberry species in the province including some dwarf species. None of these grow higher than $2 \mathrm{~m}$ (6 ft.). 


\section{Wolf Willow}

Elaeagnus commutata Bernh. ex Rydb.

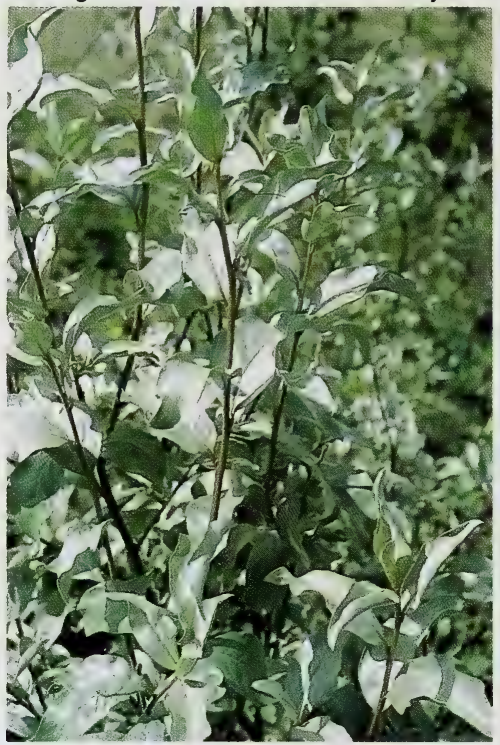

Silver-berry, Silver Buffalo-berry

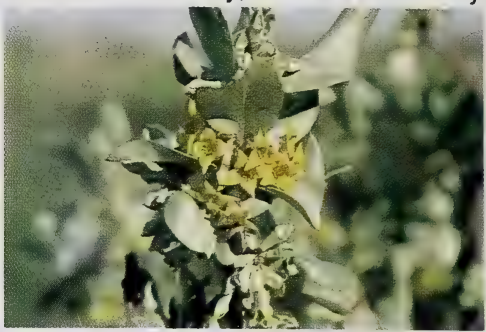

Photo by D. Johnson

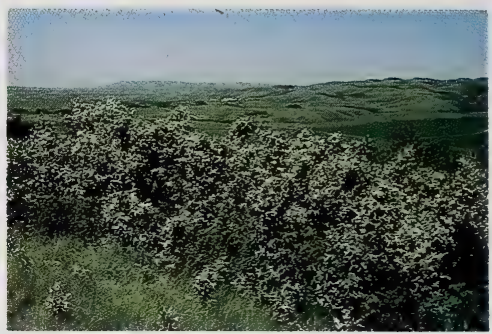

Photo by J. Hrapko

SHRUB: Grows erect, usually in thickets. Bark copper-brown, finely pebbled. SIZE: 1-3 m (3-12 ft.) high. LEAVES: Alternate, simple, oblong, $21 / 2-8 \mathrm{~cm}$ (1-3 in.) long, smooth margins; silvery-grey surface, lighter underside with brownish scales. FLOWERS: Silvery-yellow, without petals; $3 \mathrm{~mm}(1 / 8 \mathrm{in}$.) in diameter, in clusters of 2 or 3 . FRUIT: Pale silvery-green, round to oval, dry and mealy, containing a large stony seed. DISTRIBUTION: This plant prefers sand or gravelly soils and is common on valley slopes, hillsides, and in open fields throughout Alberta. In heavily grazed areas this plant spreads quickly; however, it remains sparse in the wild. Root suckering is a means by which it can propagate itself. 


\section{Canada Buffalo-Berry}

Shepherdia canadensis (L.) Nutt.

Soapberry, Soopalalie

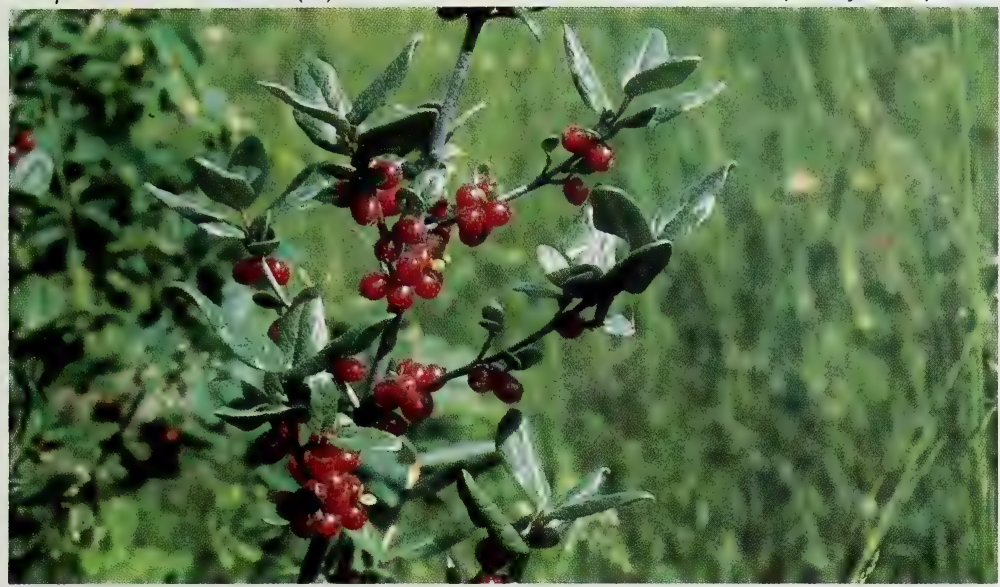

Photo by J. Hrapko

SHRUB: Sprawling, bushy appearance with several stems originating from root collar. Bark grey to black, covered with pebbly, rusty-brown scales. SIZE: $1 / 2-3 \mathrm{~m}$ (2-10 ft.) high. LEAVES: Opposite, simple, oblong, $2-5 \mathrm{~cm}(3 / 4-2$ in.) long, smooth margins; upper surface smooth, olive green; undersides silvery, with fine starshaped hairs and rusty-brown spots. FLOWERS: Small, inconspicuous, yel-

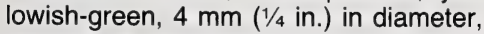
situated at leaf nodes; appear before leaves develop. FRUIT: Yellow to orangyred berries, 4-6 $\mathrm{mm}(1 / 4 \mathrm{in}$.) in diameter, in clusters along stem. DISTRIBUTION: This plant is common throughout the forested regions of the province and along river banks. It prefers well-drained sites.
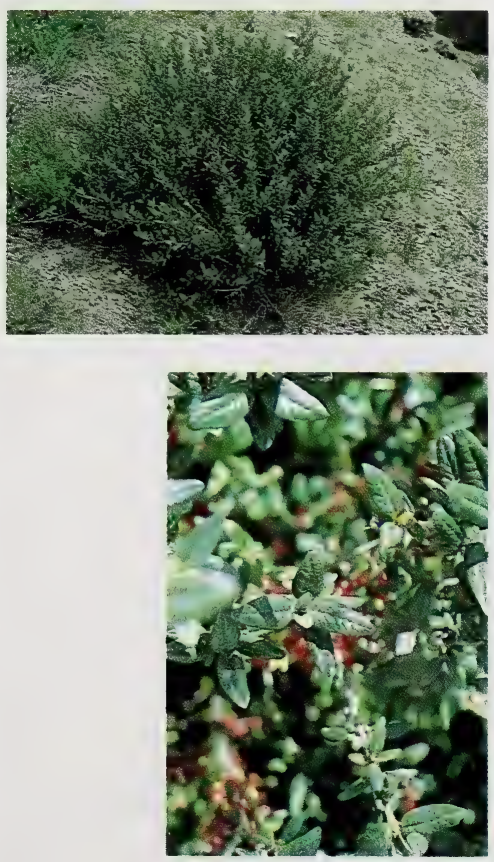


\section{Red-Osier Dogwood}

Cornus stolonifera Michx.

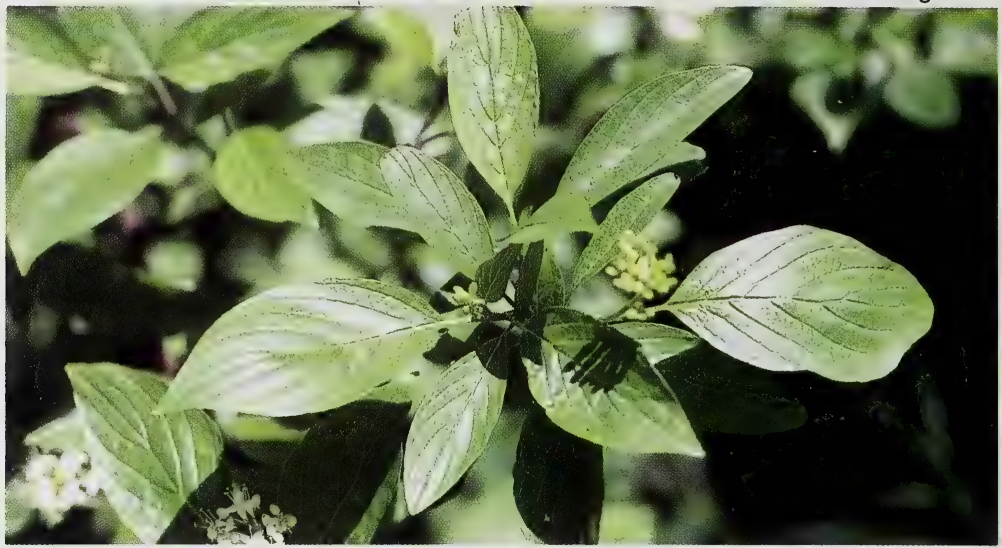

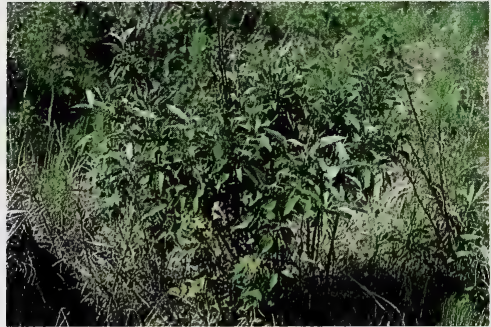

Photo by J. Hrapko

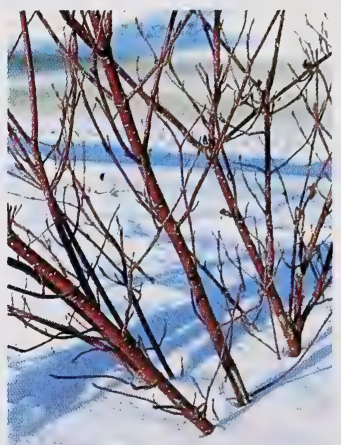

SHRUB: Straggling appearance, several stems originating from root collar. Bark red (especially in winter), with white dots on older growth. SIZE: 1-2 m (3-6 ft.) high. LEAVES: Opposite, simple, ovate, 2-8 cm (1-3 in.) long, smooth margins, prominent veins; shiny, dark green surface; underside paler with short hairs. FLOWERS: White, small, several in a flat terminal cluster; clusters $2 \frac{1}{2}-5 \mathrm{~cm}(1-2$ in.) in diameter. FRUIT: Round, greyishwhite berry (drupe), about $5 \mathrm{~mm}(1 / 4 \mathrm{in}$.) in diameter; several drupes in terminal cluster. DISTRIBUTION: This shrub is found throughout most of Alberta and prefers moist areas. It is commonly found in hardwood forests and along the sides of streams. It can spread by root suckering. 


\section{Labrador Tea}

\section{Ledum groenlandicum Oeder}
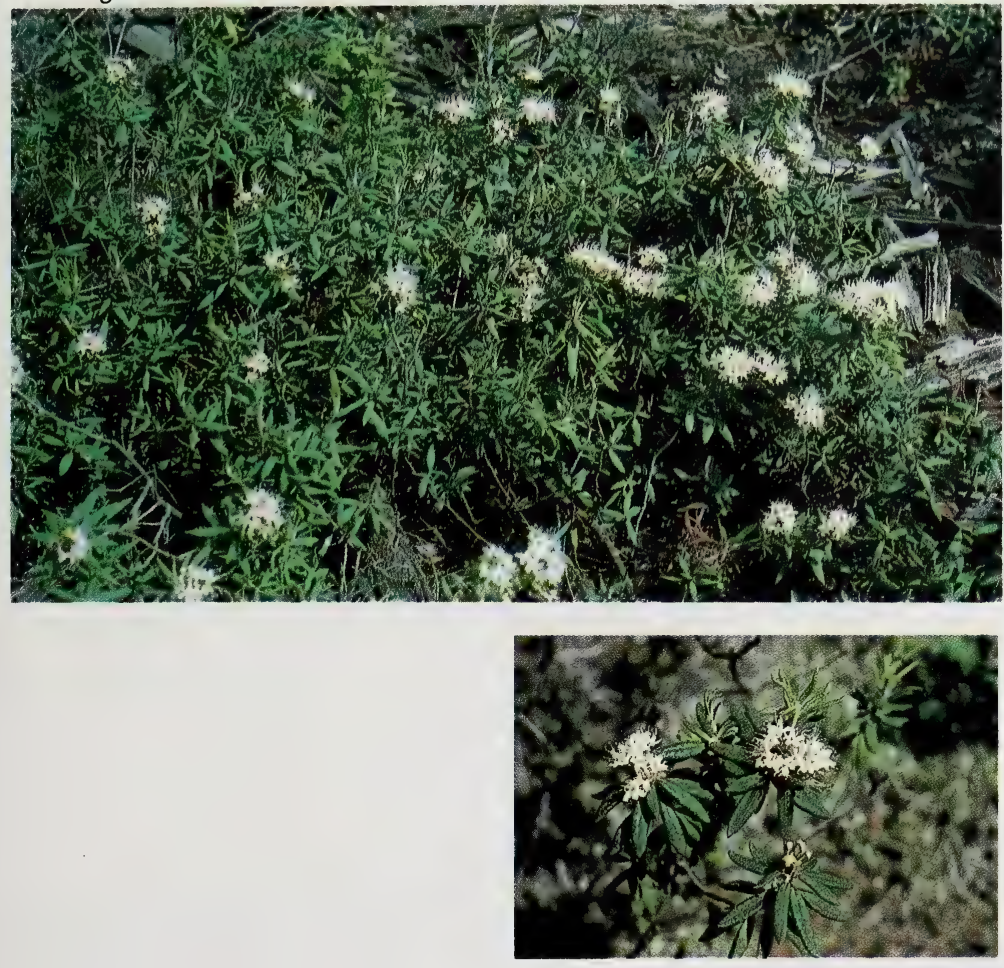

Photo by J. Hrapko

SHRUB: Low growing, erect, with many branches covered with brown, velvety hairs. SIZE: $1 / 4-1 \mathrm{~mm}$ (1-3 ft.) high. LEAVES: Alternate, simple, leathery, oblong, $1-5 \mathrm{~cm}(1 / 2-2$ in.) long; smooth margins rolled down toward underside of leaf; dark green surface; underside rustywoolly. FLOWERS: White, small with 5 petals, $6 \mathrm{~mm}(1 / 3 \mathrm{in}$.) in diameter; in dense round-topped clusters. FRUIT: Dry, oblong capsules in clusters at the ends of the branches. DISTRIBUTION: This plant is generally found in muskegs and moist coniferous woodlands in Alberta.

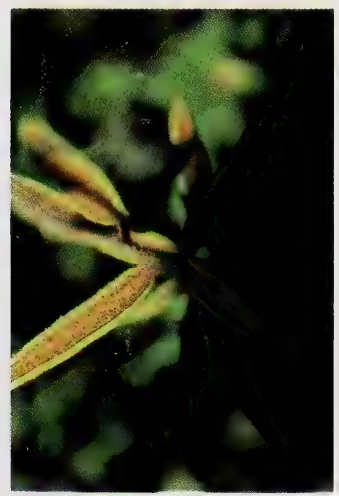




\section{Common Blueberry}

Vaccinium myrtilloides Michx.

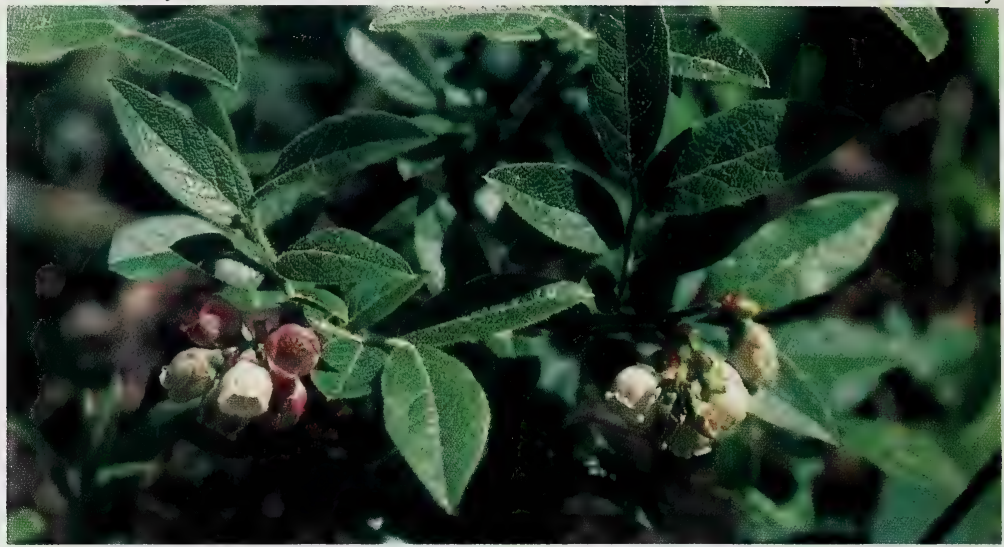

Photo by J. Hrapko

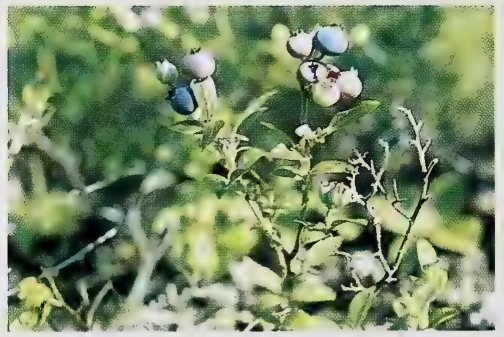

Photo by J. Hrapko

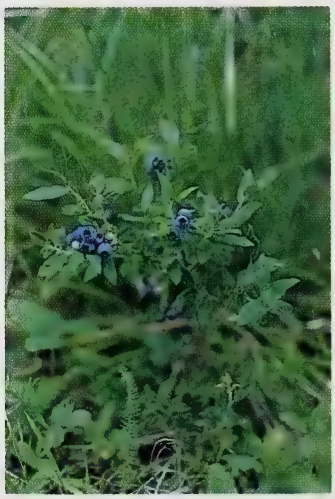

SHRUB: Low-growing shrub, usually in dense mats, with many woody, finely hairy branches thickly covered with leaves. Bark reddish-brown turning grey with age. SIZE: $1 / 4-3 / 4 \mathrm{~m}$ (1-2 ft.) high. LEAVES: Alternate, simple, thin, ellipti-

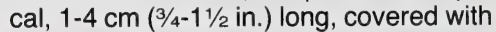
short, soft hairs; tend to hide flowers and fruit. FLOWERS: Pink or white, bellshaped, 4-5 mm ( $1 / 4$ in.) in diameter; in clusters. FRUIT: Blue berry with a whitish powdery covering, 5-6 mm ( $1 / 4$ in.) in diameter. DISTRIBUTION: Blueberries grow well on dry acidic soils of coniferous woods and on open or thinly wooded hillsides throughout the province, especially in sandy areas. NOTES: There are four other shrubs found in Alberta which are very similar to the Common Blueberry. They are all low growing shrubs with juicy, tasty, edible berries. 


\section{Bracted Honeysuckle}
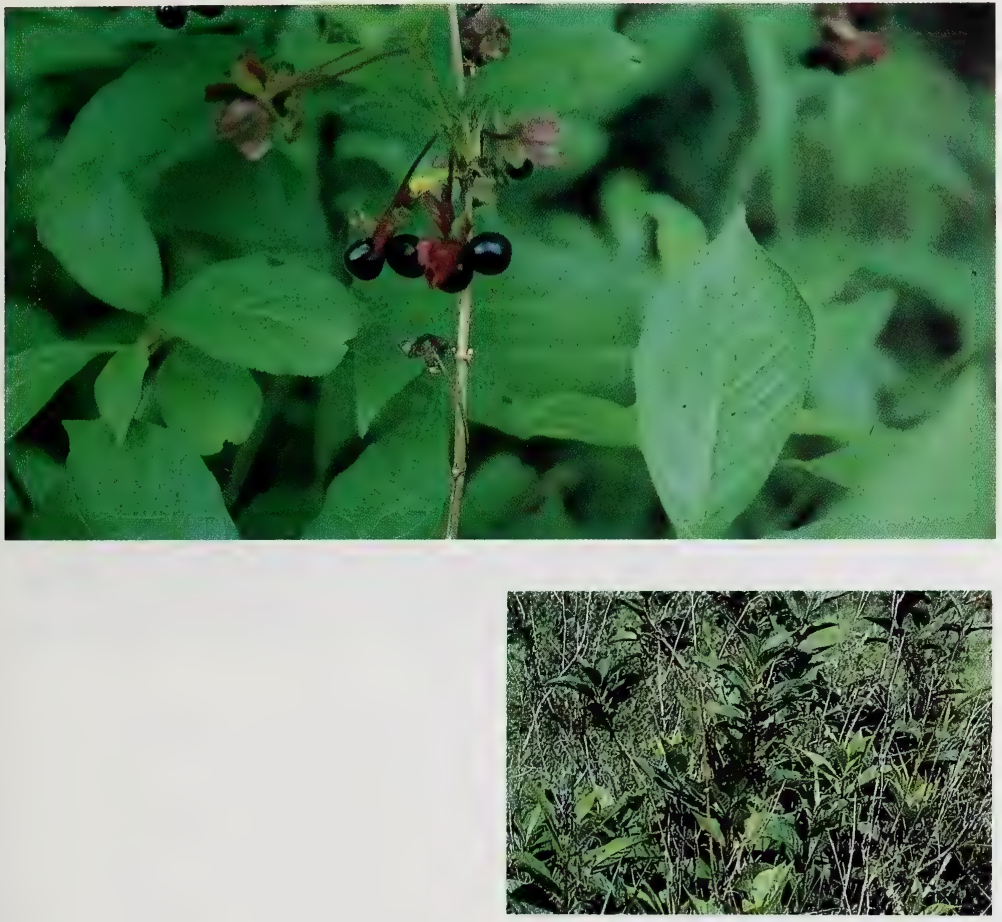

SHRUB: Bushy, with several, upwardpointing, hairy branches originating from the root collar. Light brown bark, turning grey with age. SIZE: 1-3 m (3-10 ft.) high. LEAVES: Opposite, simple, oval, $5-15 \mathrm{~cm}$ (2-6 in.) long, with a prominent mid-vein; shiny, green surface with a lighter, hairy underside. FLOWERS: Yellow, $1 \mathrm{~cm} \mathrm{(1/2}$ in.) long, paired; flanked by 2 or 4 leaflike, green or red bracts. FRUIT: Purple or black berry, $7 \mathrm{~mm}(1 / 3 \mathrm{in}$.) in diameter; paired, flanked by deep red bracts. DISTRIBUTION: This plant prefers moist rich soil and is commonly found in the forest

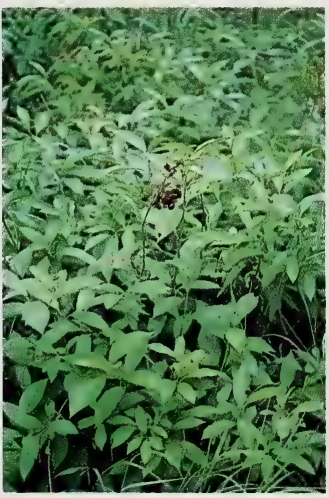
understory. 


\section{Twining Honeysuckle}

\section{Lonicera dioica $\mathrm{L}$.}
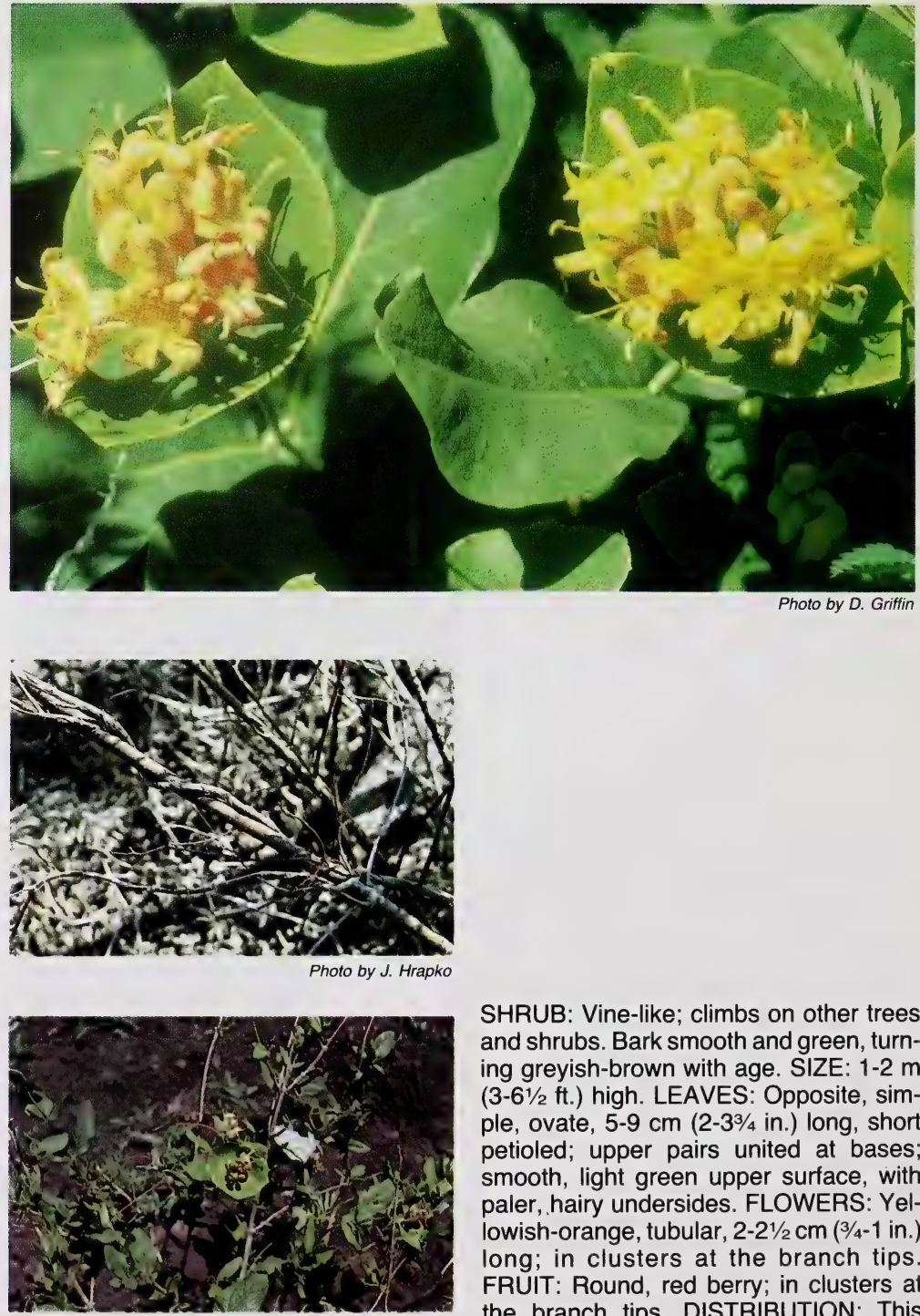

SHRUB: Vine-like; climbs on other trees and shrubs. Bark smooth and green, turning greyish-brown with age. SIZE: 1-2 m (3-6 $1 / 2 \mathrm{ft}$.) high. LEAVES: Opposite, simple, ovate, $5-9 \mathrm{~cm}(2-33 / 4$ in.) long, short petioled; upper pairs united at bases; smooth, light green upper surface, with paler, hairy undersides. FLOWERS: Yellowish-orange, tubular, $2-2 \frac{1}{2} \mathrm{~cm}(3 / 4-1$ in.) long; in clusters at the branch tips. FRUIT: Round, red berry; in clusters at the branch tips. DISTRIBUTION: This plant grows in wooded areas. It prefers shade and rich moist soil. 


\section{Buckbrush}

Symphoricarpos occidentalis Hook.

Western Snowberry, Wolfberry

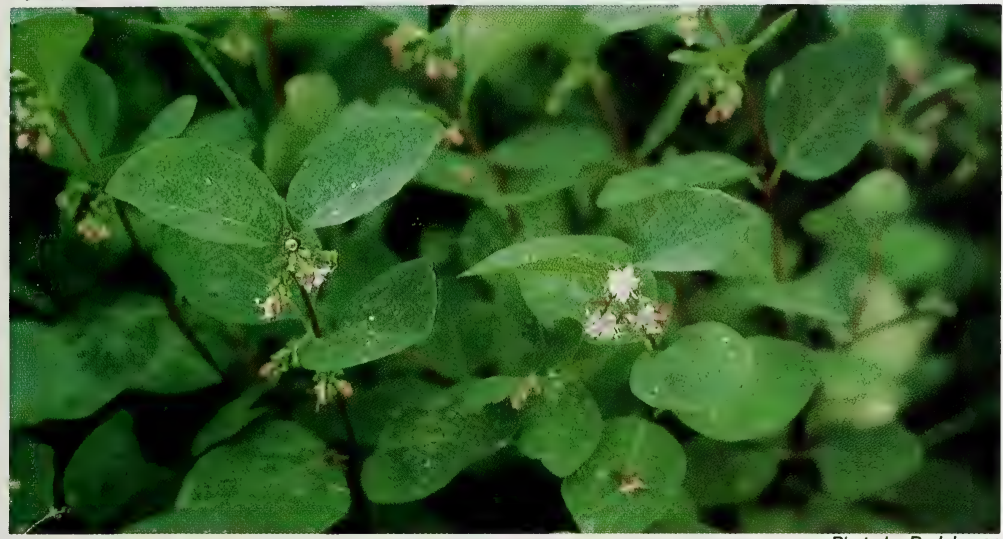

Photo by D. Johnson

SHRUB: Bushy, and grows in clumps. The stems are hollow, light grey-brown and are covered with fine, downy hair. SIZE: $30-100 \mathrm{~cm}$ (1-3 ft.) high. LEAVES: Opposite, simple, broadly oval to ovate, $2-6 \mathrm{~cm}\left(1-2 \frac{1}{2} \mathrm{in}\right.$.) long, thick and leathery; margins often wavy and occasionally coarsely toothed; light green surface, with paler hairy underside. FLOWERS: Small, bell-shaped, $6 \mathrm{~mm}(1 / 4 \mathrm{in}$.) long, pinkishwhite; form clusters at the ends of the stems. FRUIT: Greenish-white berries turning purplish with age, 8-10 mm (1/4-1/3 in.) in diameter; in clusters at the end of the stems. DISTRIBUTION: This is one of the most common and widespread shrubs in Alberta. It is found throughout the province in many habitats but prefers dry, open areas. It can spread by root suckering. NOTES: Snowberry (S. albus (L.) Blake) is similar to Buckbrush. The leaves are simple, $1 \frac{1}{2}-3 \mathrm{~cm}\left(3 / 4-1 \frac{1}{4}\right.$ in.) long and thin with smooth margins. The surface of the leaf is pale green and the underside, since it is covered with white hairs, is lighter green. Snowberry is more common in wooded areas than is Buck-

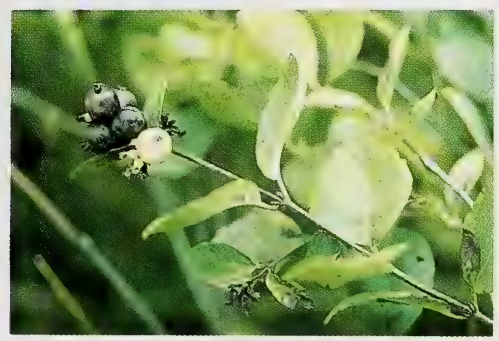

Photo by J. Hrapko

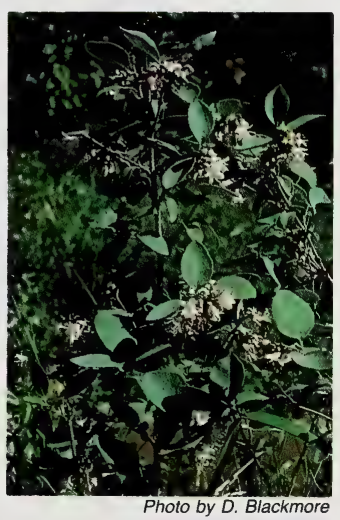
brush. 


\section{Low Bush Cranberry}

Viburnum edule (Michx.) Raf.

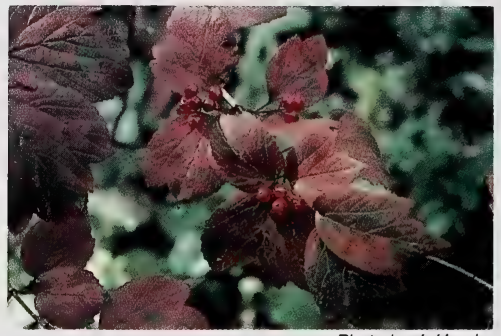

Photo by J. Hrapko
Squashberry, Mooseberry, Low HighBush Cranberry

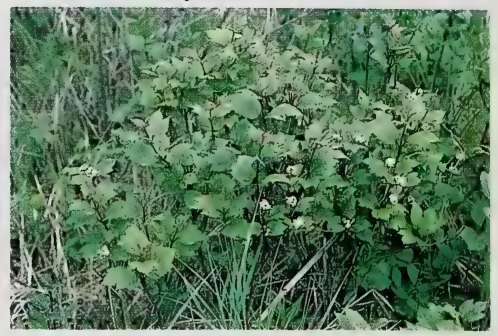

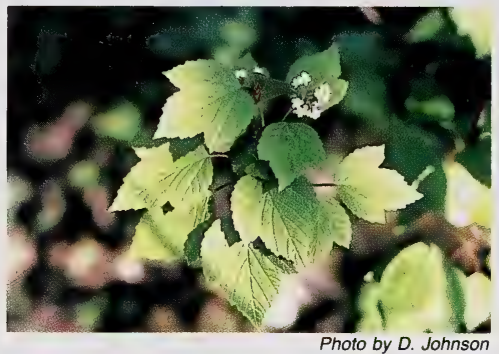

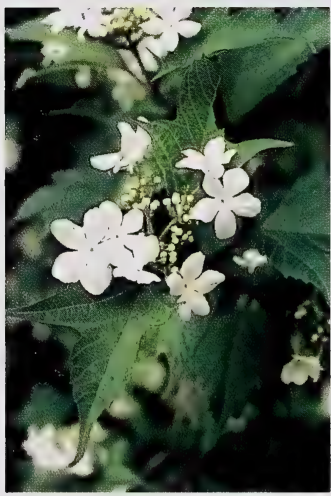

Photo by D. Griffin

High-Bush Cranberry

(V. opulus L.)
SHRUB: Medium sized with several slender, smooth, reddish-grey branches. SIZE: $1 / 2-13 / 4 \mathrm{~m}\left(1 \frac{1}{2}-6 \mathrm{ft}\right.$.) high. LEAVES: Opposite, simple, 3-lobed, $4-10 \mathrm{~cm}\left(1 \frac{1}{2}-\right.$ 4 in.) wide; toothed along margin; deeply veined, dark green surface; lighter, hairy underside. FLOWERS: Small, white, 5 petals; $7 \mathrm{~mm}(1 / 4 \mathrm{in}$.) in diameter; in flattopped clusters, $1-3 \mathrm{~cm}\left(1 / 2-1 \frac{1}{4}\right.$ in. $)$ in diameter. FRUIT: Bright red berry, with a flat seed; $1 \mathrm{~cm}(3 / 8 \mathrm{in}$.) in diameter, in clusters. DISTRIBUTION: This plant prefers to grow in rich moist soils in heavily wooded areas. It is common and widespread in Alberta's forested regions. NOTES: High-Bush Cranberry (V. opulus L.) is similar in appearance to Low-Bush Cranberry. It can grow to $4 \mathrm{~m}$ (13 ft.) in height and can be distinguished from Low-Bush Cranberry by its deeply 3lobed leaves. High-Bush Cranberry prefers to grow in forest openings and scrubby areas in river valleys and low areas. 


\section{The Importance of Shrubs to Wildlife}

\section{Shrub}

Willows

Beaked Hazelnut

Swamp Birch

Alders

Gooseberries \& Currants

Saskatoon Berry

Shrubby Cinquefoil

Pin Cherry

Choke Cherry

Rose ...

Raspberry

Wolf Willow

Canada Buffalo-Berry

Red-Osier Dogwood

Labrador Tea

Blueberry

Honeysuckle

Buckbrush

Cranberry
Big Game

Birds

1

1

2

3

2

1

2

2

2

2

2

2

3

1

3

2

2

2

1
2

1

2

2

1

1

2

1

1

1

1

2

1

1

3

1

2

1

1

SCALE: 1 = very important

$2=$ moderately important

$3=$ not important 


\section{Bibliography}

Blackmore, D.G. Alberta Tree and Shrub Identification Guide. Unpublished. Industrial Vegetation Management Association of Alberta, 1985.

Budd, Archibald C. and K.F. Best. Wild Plants of the Canadian Prairies. Publication 983. Ottawa: Canada Department of Agriculture, 1964.

Cormack, R.G.H. Trees and Shrubs of Alberta. Edmonton: Alberta Department of Lands and Forests.

Cormack, R.G.H. Wild Flowers of Alberta. Edmonton: Alberta Department of Industry and Development, 1967.

Elias, J.S. The Complete Trees of North America Field Guide and Natural History. New York: Van Nostrand Reinhold Company, 1980.

Garman, E.H. The Trees and Shrubs of British Columbia. Victoria: British Columbia Provincial Museum, Queen's Printer, 1973.

Harris, W.C. Guide to Forest Understory Vegetation in Saskatchewan. Technical Bulletin No. 9/1980, Saskatoon: Saskatchewan Tourism and Renewable Resources, Modern Press, 1980.

Hosie, R.H. Native Trees of Canada. 8th Edition. Don Mills: Fitzhenry and Whiteside Ltd., 1979.

Looman, J. and K.F. Best. Budd's Flora of the Canadian Prairie Provinces. Publication 1662. Hull: Research Branch, Agriculture Canada, 1979.

Lyons, C.P. Trees, Shrubs and Flowers to know in British Columbia. Vancouver: Evergreen Press Ltd., 1965.

Moss, E.H. Flora of Alberta. Toronto: University of Toronto Press, 1983. 
Northeastern Forest Experiment Station. Shrubs and Vines for Northeastern Wildlife. USDA Forest Service General Technical Report NE-9, 1974.

Oswald, E.T. and F.H. Nokes. Field Guide to the Native Trees of Manitoba. Winnipeg: Canadian Forestry Service, Department of Fisheries and Forestry, 1970.

Ryberg, P.A. Flora of the Rocky Mountains and Adjacent Plains. New York: Hafner Publishing Company, 1969.

Symonds, George W.D. The Tree Identification Book. Toronto: George J. McLeod Limited, 1958.

Vance, F.R., J.R. Jowsey and J.S. McLean. Wildflowers Across the Prairies. Saskatoon: Modern Press, 1977. 


\section{Index of Common and Scientific Names}

Abies balsamea, 27

lasiocarpa, 27

Alnus crispa, 34

rugosa, 34

tenuifolia, 34

Amelanchier alnifolia, 36

Aspen Poplar, 29

Balsam (Balsam Poplar), 30

Balsam Fir, 27

Balsam Poplar, 30

Beaked Filbert, 31

Beaked Hazel, 31

Beaked Hazelnut, 31

Beaked Willow, 28

Betula papyrifera, 32

pumila, 33

Black Cottonwood, 30

Black Poplar, 30

Black Spruce, 26

Black Twinberry, 47

Blueberry, 46

Bog Birch, 33

Bog Spruce, 26

Bracted Honeysuckle, 47

Buckbrush, 49

Canada Buffalo-Berry, 43

Canoe Birch, 32

Choke Cherry, 39

Common Blueberry, 46

Common Wild Rose, 40

Cornus stolonifera, 44

Corylus cornuta, 31

Currants, 35

Dogwood, 44

Dwarf Birch, 33

Elaeagnus commutata, 42

Gooseberries, 35

Green Alder, 34

High-Bush Cranberry, 50

Hoary Willow, 28
Jack Pine, 22

June-berry, 36

Labrador Tea, 45

Larch (Tamarack), 24

Larix laricina, 24

lyallii, 24

Ledum groenlandicum, 45

Lodgepole Pine, 23

Lonicera dioica, 48 involucrata, 47

Low Bush Cranberry, 50

Low High-Bush Cranberry, 50

Lyall's Larch, 24

Mooseberry, 50

Northern Gooseberry, 35

Paper Birch, 32

Picea glauca, 25

mariana, 26

Pin Cherry, 38

Pinus banksiana, 22 contorta, 23

Populus balsamifera, 30 tremuloides, 29

trichocarpa, 30

Potentilla fruticosa, 37

Prairie Rose, 40

Prickly Wild Rose, 40

Prunus pensylvanica, 38 virginiana, 39

Pussy Willow, 28

Red-Osier Dogwood, 44

Ribes, 35

hirtellum, 35

oxyacanthoides, 35

triste, 35

River Alder, 34

Rosa arkansana, 40

acicularis, 40

woodsii, 40

Rubus idaeus, 41 
Salix, 28 bebbiana, 28 candida, 28 discolor, 28 exigua, 28

Sandbar Willow, 28 Saskatoon, 36

Saskatoon-berry, 36 Service-berry, 36

Shedbush, 36

Shepherdia canadensis, 43 Shrubby Cinquefoil, 37

Silver Buffalo-berry, 42

Silver-berry, 42

Snowberry, 49

Soapberry, 43

Soopalalie, 43

Speckled Alder, 34

Squashberry, 50

Subalpine Fir, 27

Subalpine Larch, 24
Swamp Birch, 33

Swamp Honeysuckle, 47

Swamp Spruce, 26

Symphoricarpos albus, 49 occidentalis, 49

Tamarack, 24

Trembling Aspen, 29

Twining Honeysuckle, 48

Vaccinium myrtilloides, 46

Viburnum edule, 50 opulus, 50

Western Snowberry, 49

White Birch, 32

White Poplar, 29

White Spruce, 25

Wild Gooseberry, 35

Wild Red Currant, 35

Wild Red Raspberry, 41

Wolf Willow, 42

Wolfberry, 49

Willows, 28 


\section{NOTES}


NOTES 
NOTES 
NOTES 
NOTES 

National Library of Canada

Bibliotheque nationale du Canada

33286506785183 